\title{
Beware Those Bearing Gifts: Physicians' Fiduciary Duty to Avoid Pharmaceutical Marketing
}

\author{
Thomas L. Hafemeister ${ }^{*} \&$ Sarah P. Bryan ${ }^{* *}$
}

\section{INTRODUCTION}

Recently the media has spotlighted the marketing efforts of pharmaceutical companies that target physicians in an attempt to influence, directly or indirectly, the choices these physicians make about which medications to recommend and prescribe. Articles have been published with such headlines as Drug Makers Pay for Lunch as They Pitch, Is Your Doctor Tied to Drug Makers?, and The Danger in Drug Kickbacks. ${ }^{1}$ The implication of these reports is that these marketing efforts are influencing and in some instances compromising medical judgment.

Marketing drugs to physicians is nothing new. Pharmaceutical companies have been systematically pushing their products to doctors since at least the early $1950 \mathrm{~s}^{2}$ Concerns regarding the impact of this marketing on physician behavior have been expressed by patients,

J.D., Ph.D.; Associate Professor of Law, University of Virginia. The authors wish to thank Richard M. Gulbrandsen, Jr., J.D. (Associate, Bryan Cave LLP, Phoenix, AZ), and Selina Spinos, J.D. (Law Clerk, United States District Court for the Eastern District of Virginia), for their very helpful comments and suggestions.

** Anticipated J.D., 2009, University of Virginia School of Law.

1. See, e.g., Stephanie Saul, Drug Makers Pay for Lunch as They Pitch, N.Y. TIMES, July 28, 2006, at A1; Editorial, Is Your Doctor Tied to Drug Makers?, N.Y. TIMES, July 2, 2007, at A18; Editorial, The Danger in Drug Kickbacks, N.Y. TIMES, May 14, 2007, at A18.

2. Jeremy A. Greene, Pharmaceutical Marketing Research and the Prescribing Physician, 146 ANNALS INTERNAL MED. 742, 743 (2007) ("Data products relevant to prescriber profiling are collected and sold by private health care information organizations; these data products have been a central plank of pharmaceutical marketing for the past 50 years...."). An early example of pharmaceutical marketing was associated with The Great Moments in Medicine and Great Moments in Pharmacy, which were "a series of commercial paintings produced by Parke, Davis \& Company [(now a subsidiary of Pfizer)] between 1948 and 1964. Beginning in the early 1950s, Parke-Davis delivered reproductions of the Great Moments images to physicians and pharmacies throughout the United States and Canada." Jonathan M. Metzl \& Joel D. Howell, Making History: Lessons from the Great Moments Series of Pharmaceutical Advertisements, 79 ACAD. MED. 1027, 1027 (2004); Pfizer Inc., 2000: Pfizer Joins Forces with Warner-Lambert, http://www.pfizer.com/about/history/ pfizer_warner_lambert.jsp (last visited Nov. 1, 2008). 
professional organizations, commentators, legislators, and physicians themselves, and can be traced back several decades. These concerns have never really abated, but as pharmaceutical companies have become economic giants and health care costs have risen wildly, renewed media attention to the topic has brought the issue to the forefront of the debate on patient care and health care quality.

This Article begins by detailing the current state of pharmaceutical marketing, ${ }^{3}$ focusing on both the level of expenditures and the various marketing techniques used. It then discusses the positive and negative effects of this marketing. Ultimately, although noting that regulations and guidelines try to help curb the negative aspects of marketing, the Article concludes that these efforts are largely unsuccessful in preventing pharmaceutical marketing's undue and unhealthy influence on physicians and the broader health care system.

This Article then argues that the most effective way to curtail the potentially deleterious effects of marketing is to recognize that physicians have a fiduciary duty to give the well-being of their patients the highest priority. This fiduciary duty, this Article asserts, includes a subsidiary obligation to avoid pharmaceutical marketing when patients' interests may be compromised. In turn, a failure to meet this obligation would potentially expose physicians to a cause of action for breach of their fiduciary duty. This Article will subsequently outline the specific structure for a breach of fiduciary duty claim based on a physician's failure to avoid insidious pharmaceutical marketing practices that compromise his or her medical judgment. Finally, this Article will address the challenges and benefits of constructing and implementing such a duty.

\section{MARKETING EXPENDITURE AND SCOPE}

The composite amount spent on pharmaceutical marketing in this country is hard to pinpoint, but available figures indicate it is around $\$ 12$ billion annually. ${ }^{4}$ Concerned about rising expenditures on marketing,

3. This Article addresses only pharmaceutical marketing, which encompasses systematic efforts by pharmaceutical companies to induce physicians to prescribe their drugs. Marketing should be distinguished from advertising, which typically refers to pharmaceutical companies' efforts to target patients/consumers directly, also known as Direct to Consumer Advertising or DTCA. There has also been significant marketing of medical products. However, this Article limits itself to a discussion of pharmaceutical marketing.

4. Sheryl Calabro, Note, Breaking the Shield of the Learned Intermediary Doctrine: Placing the Blame Where It Belongs, 25 CARDOZO L. REV. 2241, 2257 (2004) ("Annually, the pharmaceutical industry spends $\$ 12$ billion promoting and marketing their products to physicians 
Congress at one point considered a bill that would have eliminated tax incentives supporting the industry's gifts to physicians. ${ }^{5}$ The bill listed findings that: "(1) drug company expenditures on marketing and administration are twice research and development expenditures, (2) the pharmaceutical industry annually spends $\$ 11,000,000,000$ promoting and marketing their products ..., [and] (3) drug companies annually spend $\$ 8,000$ to $\$ 13,000$ per physician on such promotions." ${ }^{\prime 6}$ Despite increased spending on Direct-to-Consumer Advertising beginning in the mid-1980s when regulations regarding these advertisements were relaxed, ${ }^{7}$ expenditures on physician marketing have continued to rise. ${ }^{8}$

The great majority of these expenditures are spent on "detailing." Detailing is the term used to denote the practice of pharmaceutical representatives visiting the offices of physicians or otherwise contacting physicians to promote their company's drugs and/or medical devices. Detailers provide physicians with handouts, pharmaceutical samples, "freebies" like textbooks and stethoscopes, and sponsorships for continuing medical education programs. ${ }^{9}$ As of February 2007, there

through gifting, travel reimbursements and meal expenses, with approximately $\$ 10,000$ being spent on each individual physician." (citing H.R. 2641, 107th Cong. (2001))); Stephanie Greene, False Claims Act Liability for Off-Label Promotion of Pharmaceutical Products, 110 PENN ST. L. REV. 41, 42 (2005) ("[T]he $\$ 2.4$ billion spent on consumer advertising pales in comparison to the more than $\$ 8$ billion spent each year on marketing to physicians." (citing Marcia Angell \& Arnold S. Relman, America's Other Drug Problem, The New Republic, Dec. 16, 2002, at 34)); Marshall B. Kapp, Drug Companies, Dollars, and the Shaping of American Medical Practice, 29 S. ILL. U. L.J. 237, 241 (2005) ("In 2001, the American pharmaceutical industry spent $\$ 12.5$ billion on marketing its products, equaling approximately $\$ 10,000$ per licensed physician, a $50 \%$ increase since $1998 . "$ (citing Scott Hensley, Doctors Are Found to Be Susceptible to Drug Pitches, Wall St. J., Dec. 12, 2002, at D6)); Tobias L. Millrood, When Drug Sales Representatives Go Too Far, Winter 2007 AM. ASS'N JUSTICE-CLE 521 (2007) ("By 2000, pharmaceutical companies spent \$15.7 billion promoting their products, with the largest share (84\%) directed toward medical professionals through commercial detailing, drug samples, and journal advertisements." (citing M.B. Rosenthal et al., Promotion of Prescription Drugs to Consumers, 346 New ENG. J. MED. 498 (2002))); Natasha Singer, No Lipitor Mug? Drug Makers Cut Out Goodies for Doctors, N.Y. TIMES, Dec. 31, 2008, at A1 ("[In 2008], besides giving away nearly $\$ 16$ billion in free drug samples to doctors, pharmaceutical companies spent more than $\$ 6$ billion on 'detailing' - an industry term for the sales activities of drug representatives including office visits to doctors, meal-time presentations and branded pens and other handouts." (citing IMS Health, a health care information company)).

5. Save Money for Prescription Drug Research Act of 2000, H.R. 4088, 106th Cong. (2000). The bill died in the House and never became law. A further discussion of state and federal legislative efforts to remedy the perceived problem of pharmaceutical marketing will follow in Part IV.C, infra notes 133-58 and accompanying text.

6. H.R. 4088.

7. See Lars Noah, Advertising Prescription Drugs to Consumers: Assessing the Regulatory and Liability Issues, 32 GA. L. REV. 141, 147 (1997) (noting that in 1985, the FDA lifted a two-year moratorium on direct to the consumer advertising).

8. Sara Selis, Study Calculates Outlay of Pharmaceutical Research: Drug Companies Promote Through Multiple Channels, STAN. REP., May 21, 2003, available at http://news-service. stanford.edu/news/2003/may21/pharma.html.

9. Id.; Millrood, supra note 4. 
were approximately 100,000 detailers (i.e., pharmaceutical representatives) pursuing approximately 200,000 physicians who prescribe pharmaceuticals. $^{10}$ Detailers are primarily college-educated, and complete training programs specifically tailored to enable them to promote the company's drugs. ${ }^{11}$ It has been noted that "[a] pharmaceutical representative will often try to see a given physician every few weeks" and that "[r]epresentatives often have a call list of about 200 physicians with 120 targets that should be visited in four to six week cycles." "Physicians meet with detailers as often as three to five times each week," 13 with an average of ten representatives a month visiting them. ${ }^{14}$

Not all physicians have the same number of detailers requesting to meet with them, and not all physicians meet with the detailers who visit their office. Using data on physicians' prescribing habits purchased for nearly \$20 million from the American Medical Association (AMA), firms hired by pharmaceutical companies "attempt to identify [those] physicians most likely to prescribe a particular drug." "“deciled' into 10 groups based on their [prescription-]writing patterns," which are determined by looking at a physician's weekly total number of prescriptions and number of new prescriptions. ${ }^{17}$ Those in the "[h]igher deciles are more aggressively targeted." 18 Thus, doctors who write the largest numbers of prescriptions receive the greatest number of visits from detailers. ${ }^{19}$ "An AMA study found that physicians who [write] one to ten prescriptions per week [see] 2.33 detailers per week, whereas those

10. Millrood, supra note 4.

11. Bureau of Labor Statistics, Department of Labor, Pharmaceutical and Medicine Manufacturing, http://www.bls.gov/oco/cg/cgs009.htm (last visited Nov. 1, 2008).

12. Millrood, supra note 4.

13. Susan Heilbronner Fisher, Note, The Economic Wisdom of Regulating Pharmaceutical “Freebies," 1991 DUKE L.J. 206, 210 (1991).

14. Greene, supra note 4, at 42 (citing CARL Elliott, BETTER THAN Well: AMERICAN MEDICINE MEETS THE AMERICAN DREAM 120 (W.W. Norton \& Co. 2003)).

15. See Calabro, supra note 4, at 2259-60 (noting "the AMA stands to lose more than $\$ 20$ million a year if forced to stop selling data to drug manufacturers").

16. See Millrood, supra note 4 ("There are a number of firms that specialize in data and analytics for pharmaceutical marketing: ASI, Bayser, Campbell Alliance, CommodiCast, Cozmix, Dendrite, Getronics, Health Market Science (HMS), Health Products Research (HPR), iMetrikus, IMpactRx, IMS Health, Ingenix, LeapFrogRx, MarketRx, Medstat, Meta Pharmaceutical Services, LLC, Microsoft Life Sciences, NDCHealth, Premier, Questerra, SAP, Siebel Systems, Spotfire, Sybase, TargetRx, Tegra, Analytics, The Patient Connection, Trinity Partners, Verispan, ZDNet, and ZS Associates are several of the third-party outlets used.").

17. $I d$.

18. Id.

19. Fisher, supra note 13 , at 226-27. 
who [write] over 150 prescriptions weekly [receive] 8 visits." ${ }^{20}$ In making marketing decisions, companies may also consider the:

(1) [p]rofitability of [the] prescription ...; (2) [a]ccessibility of the physician; (3) [t]endency of the physician to use the pharmaceutical company's drugs; (4) [e]ffect of managed care formularies on the ability of the physician to prescribe a drug; (5) ... adoption sequence of the physician (that is, how readily the physician adopts new drugs in place of older, established treatments); (6) ... tendency of the physician to use a wide palette of drugs; and (7) [i]nfluence that physicians have on their colleagues. ${ }^{21}$

Despite this aggressive targeting, physicians' average total time spent with detailers is not staggeringly high; on average, physicians usually spend less than one minute with each pharmaceutical representative per visit. ${ }^{22}$ This suggests that a significant number of detailers are sent away without seeing physicians for anything more than a cursory hello. Anecdotal evidence supports this conclusion. ${ }^{23}$

Because of the often hasty nature of these meetings, pharmaceutical representatives regularly leave reminders such as "notepads, pens, rulers, and other useful 'freebies' engraved with the logo of the drug company and the product's name" to enhance a new drug's name recognition. ${ }^{24}$ Detailers also leave drug samples with the physician. ${ }^{25}$ This "sampling" is frequently "considered a paradigmatic example of pharmaceutical promotions," and because of the substantial expenditures involved in the distribution of samples to medical providers, this practice "has been studied extensively."26 It has been argued that sampling allows

20. Id. (citing H. Walker, Market Power and PRICE Levels in the Ethical DRUG MARKET 74 (Indiana U.P. 1971)).

21. Millrood, supra note 4.

22. Greene, supra note 4 , at 42 .

23. Interview with Barbara Allison-Bryan, M.D. (Nov. 12, 2007).

24. Fisher, supra note 13, at 210 . Other "freebies" received by physicians include: golf balls with a company or drug logo, rulers, pens, pencils, note pads, mugs, glasses, cups, hats, caps, shirts, magnets, towels, tie tacks, clipboards, a large variety of anatomic models, games, puzzles, socks, visors, packages of candy, gum, popcorn, tickets to shows, dinners, weekend getaways, golf fees, tennis balls, and cash.

Id. at 210 n.20 (quoting Advertising, Marketing and Promotional Practices of the Pharmaceutical Industry: Hearings Before the S. Comm. on Labor and Human Res., 101st Cong. 101 (1990) (testimony of Dr. John C. Nelson)).

25. Id. at 210

26. Id. at 231. One pharmaceutical representative reported that "the sample budget for one product could easily exceed the total journal advertising expenditure for all products." William D. French, Perspectives, A Delicate Balance: A Perspective on Pharmaceutical Sampling, 124 ARCHIVES DERMATOLOGY 588, 588 (1988). 
"doctor[s] and patient[s] to try the product and ... physicians to provide free samples to needy patients." 27

But not all meetings between physicians and detailers are that hurried. "Detailers frequently treat doctors[, including] hospital residents, to lunches or dinners" to discuss the company's products. ${ }^{28}$ Lunches supplied by drug representatives were highlighted in a very skeptical August 4, 2006 editorial in the New York Times:

At a four-story medical building in New Hyde Park on Long Island, steaming containers of Chinese food and trays of gourmet sandwiches were delivered to receptive medical practices, courtesy of various drug companies. Sometimes morning pastries and coffee were on the menu as well.

... Merck was happy to pay $\$ 258$ to provide Chinese food to the 20 or more doctors and employees of a pulmonary practice so that its sales representatives could tout the virtues of an osteoporosis drug and an asthma treatment in a relaxed setting. Nationwide, such lunches are believed to cost the pharmaceutical industry hundreds of millions of dollars a year, a marketing cost the companies are happy to absorb in hopes of bolstering sales of high-priced prescription drugs.

One commentator added that "companies also conduct dinner-lecture programs in which physicians enjoy a meal (typically in a fine restaurant) while listening to a . . lecture on a medical condition that the sponsor's medication is intended to treat." 30 Pharmaceutical companies apparently have found that their detailers are more likely to be able to get in a few words about their product if they come bearing food.

Pharmaceutical companies also hire physicians to do some of their promotional work by joining a detailer on office visits, by giving lectures to groups of physicians, or by participating in clinical research studies. In a recent article, Dr. Daniel Carlat, a psychiatrist in Massachusetts, recounted his experience as a physician lecturer for Wyeth Pharmaceuticals, the producer of Effexor XR, a drug to treat depression. $^{31}$ In 2001, he was "flown to New York for a 'faculty-

27. Fisher, supra note 13, at 231 (citing French, supra note 26, at 588). A rebuttal to this assertion is considered later in this Article. See infra notes 81-84 and accompanying text.

28. Fisher, supra note 13 , at 210.

29. Editorial, Please Hold the Free Lunches, N.Y. TIMES, Aug. 4, 2006, at A16.

30. Jeffrey T. Berger, Pharmaceutical Industry Influences on Physician Prescribing: Gifts, Quasi-Gifts, and Patient-Directed Gifts, 3 AM. J. BioETHICs 56, 56-57 (Summer 2003).

31. Daniel Carlat, Dr. Drug Rep, N.Y. Times, Nov. 25, 2007, Section 6 (Magazine), at 64; see also Jacob Goldstein, How Drug Industry Money Affected a Psychiatrist's Judgment, WALL ST. J., Nov. 26, 2007, http://blogs.wsj.com/health/2007/11/26/how-drug-industry-money-affected-a- 
development program' [and] ... 'pampered in a Midtown hotel for two nights" " to educate him about the product. ${ }^{32} \mathrm{He}$ was subsequently paid between $\$ 500$ and \$750 for a one-hour "Lunch and Learn" in which he spoke at local doctors' offices about Effexor. ${ }^{33}$ In one year of speaking to doctors on behalf of Wyeth, he made approximately $\$ 30,000$ in supplementary income. ${ }^{34} \mathrm{He}$ recognized that he persuaded many physicians to prescribe Effexor, and posited that his lectures may have contributed to "faulty medical decision making" or led doctors "to make inappropriate drug choices" that may have made "their patients suffer needlessly" from Effexor's poorly published, but significant withdrawal symptoms. ${ }^{35}$ Accounts similar to those of Dr. Carlat have been provided by others. ${ }^{36}$

Pharmaceutical companies also supply large levels of funding for clinical research. Nearly seventy-five percent of all funding for clinical trials in the United States comes from corporate sponsors. ${ }^{37}$ "Increasingly, clinicians are invited ... to participate in clinical trials of newly developed drugs, ... often [by] enrolling their own patients as subjects." 38 The sponsor of the research hires physicians to conduct at least a portion of the clinical trial. These doctors may have an academic affiliation or be clinicians associated with non-academic hospitals or in private practice. "Doctors are often paid to recruit patients to [these] clinical trials," usually on a per-patient basis. ${ }^{39}$ In Britain, payments have been up to thousands of pounds per patient who completes the clinical trial. ${ }^{40}$ It has been noted that a "[w]ell organised British general practice[] can earn an extra $£ 15,000$ annually for three hours' work a

psychiatrists-judgment/

32. Carlat, supra note 31 , at 64 .

33. Id.

34. Id. at 69

35. Id.

36. Is Your Doctor Tied to Drug Makers?, supra note 1, at A18 ("[O]ne drug company invited doctors to a weekend training session in Orlando, Fla., to learn how to give marketing lectures to other doctors for an asthma medicine. The enticement was free airfare, a rental car and hotel room, plus a $\$ 2,700$ stipend.").

37. Sameer S. Chopra, Industry Funding of Clinical Trials: Benefit or Bias?, 290 JAMA 113, 113 (2003) (citing Thomas Bodenheimer, Uneasy Alliance: Clinical Investigators and the Pharmaceutical Industry, 342 NEw ENG. J. Med. 1539, 1539 (2000)).

38. Susan L. Coyle, Physician-Industry Relations. Part I: Individual Physicians, 136 AnNALS INTERNAL MED. 396, 399 (2002).

39. Jammi N. Rao \& L.J. Sant Cassia, Ethics of Undisclosed Payments to Doctors Recruiting Patients in Clinical Trials, 325 BRIT. MED. J. 36, 36 (2002); Center Watch: Clinical Trials Listing Service, Background Information on Clinical Research, http://www.centerwatch.com/patient/ backgrnd.html\#Section3 (last visited Nov. 1, 2008).

40. Rao \& Sant Cassia, supra note 39, at 36. 
week." 41 In the United States, a November 2004 study published in the Journal of General Internal Medicine reported that thirty-seven percent of Maryland internists surveyed "engag[ed] in pharmaceutical-sponsored clinical trials and/or lectures to supplement their incomes."

Pharmaceutical companies also regularly sponsor Continuing Medical Education (CME) programs, a certain number of which physicians are mandated to attend to maintain their licensure. ${ }^{43}$ The industry provides "a substantial proportion of the several billion dollars spent on CME annually," allowing industry to influence nearly every aspect of the CME programming. ${ }^{44}$ This may include organizing and advertising the event; preparing teaching slides and curriculum materials; compiling lists of possible speakers, who may also be recipients of funding for clinical research supplied by the pharmaceutical company; subsidizing the attendance of practitioners, medical students, residents, and fellows; and providing free meals and other amenities for attendees at these programs. "At, or adjacent to, virtually all educational sessions subsidized by industry, [pharmaceutical] sales representatives are allowed to display and promote the company's products, particularly [those] related to the [focus] of the program. ${ }^{, 46}$ Educational materials

41. Id. at 36 (citing Income Generation, MEDECONOMICS, Aug. 1996, at 44).

42. Bimal H. Ashar et al., Prevalence and Determinants of Physician Participation in Conducting Pharmaceutical-Sponsored Clinical Trials and Lectures, 19 J. GEN. INTERNAL MeD. 1140,1140 (2004). Aside from the fact that the pharmaceutical industry-sponsored clinical trials may influence the prescribing behavior of the physicians conducting the research, clinical trials sponsored by pharmaceutical companies have themselves been the target of considerable criticism. See Catherine D. DeAngelis, Editorial, Conflict of Interest and the Public Trust, 284 JAMA 2237, 2237 (2000) ("The problem lies in the conflict of interest that results from these relationships."). They have been asserted to be "lower in quality [and] more likely to favor the sponsor's product." Id. at 2238 (citing Paula A. Rochon, Evaluating the Quality of Articles Published in Journal Supplements Compared with the Quality of Those Published in the Parent Journal, 272 JAMA 10813 (1994)); see also Lisa A. Bero et al., The Publication of Sponsored Symposiums in Medical Journals, 327 NEw ENG. J. MED. 1135, 1135-40 (1992); Lisa A. Bero \& Drummond Rennie, Influences on the Quality of Published Drug Studies, 12 InT'L J. TeCH. ASSESSMENT HeAlth CARE 209, 209-37 (1996); Mildred K. Cho \& Lisa A. Bero, The Quality of Drug Studies Published in Symposium Proceedings, 124 ANNALS INTERNAL MED. 485, 485-89 (1996); David Blumenthal et al., Withholding Research Results in Academic Life Science, 277 JAMA 1224, 1224-28 (1997); Mark Friedberg et al., Evaluation of Conflict of Interest in Economic Analyses of New Drugs Used in Oncology, 282 JAMA 1453, 1453-57 (1999); Paula A. Rochon et al., A Study of ManufacturerSupported Trials of Nonsteroidal Anti-inflammatory Drugs in the Treatment of Arthritis, 154 ARCHIVES INTERNAL MED. 157, 157-63 (1994).

43. Arnold S. Relman, Separating Continuing Medical Education from Pharmaceutical Marketing, 285 JAMA 2009, 2009-12 (2001).

44. Id. at 2009; see also Kapp, supra note 4, at 247 ("CME financial sponsorship may substantially influence the subsequent prescribing behavior of physician attendees; in other words, this form of promoting its product 'works' for drug companies.").

45. Relman, supra note 43, at 2009.

46. Id. 
are prepared by the pharmaceutical company, and physicians are paid honoraria to lecture at CME events or other speaking engagements with an implicit understanding that the physician will mention the sponsoring company's product. ${ }^{47}$

And finally, pharmaceutical companies have been known to provide physicians "payment for attending meetings of specious advisory boards at which little advising by physicians, and a great deal of marketing to physicians, occurs." ${ }^{48}$ "Physicians might be further enticed to attend [these meetings] with the promise of a gift check to be used for "professional or practice-related' activities."

Pharmaceutical companies and physicians have been encouraged through their respective codes of practice to make these connections at least partially public. ${ }^{50}$ Conference speakers and authors of research papers are required to note any potential conflict of interest, including the receipt of funding from a pharmaceutical company. ${ }^{51}$ However, the amount and frequency of payment are not necessarily revealed. As a result, the disclosures made may be limited and relatively perfunctory. ${ }^{52}$

Rarely is there an explicit quid pro quo for this funding, but implied ones abound. ${ }^{53}$ When funding or "educational grants" are provided for lavish trips to golf and ski resorts, cocktail parties, office holiday parties, and travel, the pharmaceutical manufacturers' goal is relatively obvious. These are rewards for writing large numbers of prescriptions. And, for example, as soon as Dr. Carlat, the physician being sponsored by Wyeth, began to give less enthusiastic presentations about Effexor, the pharmaceutical company became much less enthusiastic about him. $\mathrm{He}$ wrote: the "manager's message couldn't [have been] clearer: I was being paid to enthusiastically endorse their drug. Once I stopped doing that, I was of little value to them, no matter how much 'medical education' I

47. Fisher, supra note 13, at 211-12.

48. Berger, supra note 30 , at 56.

49. Id.

50. See, e.g., AM. MEd. Ass'N, Code Of MEdiCAL Ethics, Gifts to Physicians from Industry, E-8.061(3); Pharmaceutical Research and MANufaCturers of AMERICA (PhRMA) CODE ON InTERACTIONS With HEAlth CARE PROFESSIONALS, Speaker Programs and Speaker Training Meetings, § 7, at 9, available at http:/www.phrma.org/files/PhRMA\%20Marketing\%20Code\% 202008.pdf.

51. See David M. Studdert et al., Financial Conflicts of Interest in Physicians' Relationships with the Pharmaceutical Industry-Self-Regulation in the Shadow of Federal Prosecution, 351 NEW ENG. J. MED. 1891, 1894 (2004).

52. See Relman, supra note 43, at 2010; Interview with Barbara Allison-Bryan, M.D. (Mar. 23, 2008).

53. Kapp, supra note 4, at 249. 
provided." ${ }^{, 54}$ Because he no longer gave glowing recommendations about the drug, the opportunities for monetary rewards ceased.

Pharmaceutical companies have developed numerous ways to try to influence physicians in their prescribing habits, including detailing, freebies, samples, meals, trips, as well as payments for training presentations, speeches, and continuing medical education programs. Nearly every practicing physician is exposed to at least one or more, if not all of these marketing techniques. ${ }^{55}$ Although the effects of these practices on physician behavior have already been implied, the next section will discuss the direct impact these marketing practices have on medical care.

\section{The EFFECts of PharmaceUticAl MARKETING ON PATIENT CARE}

It should be acknowledged that benefits, beyond increasing the revenue of pharmaceutical companies, can flow from pharmaceutical marketing. Some studies have uncovered "a positive [correlation] between high promotional spending" and the entry of new companies and drugs into the market, with the marketing efforts enhancing competition within the industry. ${ }^{56}$ In addition, advertising by pharmaceutical companies in medical journals has decreased the price of journal subscriptions. ${ }^{57}$ Marketing also generates necessary income to fund research and development on new drugs. ${ }^{58}$ As explained by one commentator:

Pharmaceutical [research and development] is a tedious process, requiring extensive expenditures of time and money, yet uncovering very few successful products. Therefore, when a company develops what seems to be an innovative chemical compound with unique therapeutic applications, it must recoup enough of its costs to pay for its numerous and expensive failed attempts. Moreover, a company with a new product must recoup these costs during the seventeen or eighteen years of the patent term, before the generic drug makers assume their

54. Carlat, supra note 31 , at 69

55. Because $\mathrm{CME}$ is mandatory for physicians to maintain their license, it would be very surprising if any physician could completely cut off his or her exposure to pharmaceutical marketing.

56. Fisher, supra note 13, at 225 (citing P. FELdSTEIn, HEALTH CARE ECONOMiCs 448 (3d ed. 1988)); see also Fiona M. Scott Morton, Barriers to Entry, Brand Advertising, and Generic Entry in the US Pharmaceutical Industry, 18 INT'L J. INDUS. ORG. 1085, 1103 (2000).

57. E. de Laat et al., How Does Pharmaceutical Marketing Influence Doctors' Prescribing Behaviour?, CPB REPORT: QuARTERLy REVIEW OF CPB NETH. BUREAU ECON. POL'y ANALYSIS 56, 64 (2002) (discussing research conducted in American journals).

58. Fisher, supra note 13, at 222. 
portion of the market. At the same time, producers run the risk that another manufacturer will create a more effective patentable product for the same illness. This entire process has an extremely short fuse, and the need for companies to expend large sums for rapid-fire marketing is obvious. ${ }^{59}$

Pharmaceutical marketing also allows physicians to learn about the newest approaches and drugs on the market. For medications to be able to help patients, physicians must learn about their availability. ${ }^{60}$ It is both expensive to communicate this information to physicians, and expensive (in terms of lost time) for physicians to absorb the information. ${ }^{61}$ Pharmaceutical companies may be in the best position to bear the costs of transmitting this information and should be able to play a pivotal role in this dissemination. ${ }^{62}$ Furthermore, traditionally, a pharmaceutical manufacturer must warn the physician of the side effects and other risks of their prescription drugs. ${ }^{63}$ Marketing drugs, especially through detailers or lectures, gives companies the opportunity to do this, although in practice the conversations between detailers or lecturers and physicians may not fully or even adequately supply the needed information. ${ }^{64}$

59. Id. at 222-23 (citing Prescription Drug Cost Increases: Factors and Trends: Hearing Before the Subcomm. on Health \& the Env't of the H. Comm. on Energy \& Commerce, 100th Cong. 262-64 (1987) (testimony of Gerald Mossinghoff)); see also FELDSTEIN, supra note 56, at 453 ("The uncertainty of returns to research and development expenditures contains an element of risk that is perhaps greater than in other industries."); Prafulla Joglekar \& Morton L. Paterson, A Closer Look at the Returns and Risks of Pharmaceutical R\&D, 5 J. HEALTH ECON. 153, 175 (1986) (noting that "only one in three" new chemical entities offers a better return than an investment in a bond, "and the odds of exceeding it by an appreciable degree are small indeed"). Cf. Marcia Angell, Excess in the Pharmaceutical Industry, 171 CAN. MED. Ass'N. J. 1451, 1451 (2004) ("Although the pharmaceutical industry claims to be a high-risk business, year after year drug companies enjoy higher profits than any other industry. In 2002, for example, the top 10 drug companies in the United States had a median profit margin of $17 \%$, compared with only $3.1 \%$ for all the other industries on the Fortune 500 list." (citing N. Pattison \& L. Warren, 2002 Drug Industry Profits: Hefty Pharmaceutical Company Margins Dwarf Other Industries, Public Citizen Congress Watch (June 2003), available at www.citizen.org/documents/Pharma_Report.pdf)).

60. See Paul H. Rubin, Pharmaceutical Marketing: Medical and Industry Biases, $13 \mathrm{~J}$. PhARMA. FIn., ECON. \& POL'Y 65, 65 (2004).

61. See id.

62. Id. He also notes that what may appear as "bribery" could be viewed as compensation to the physicians for the opportunity cost of time to learn about drugs. Id.

63. Restatement (ThiRd) OF TORTS: Prod. LiAB. § 6 (1998); Ozlem A. Bordes, The Learned Intermediary Doctrine and Direct-to-Consumer Advertising: Should the Pharmaceutical Manufacturer Be Shielded from Liability?, 81 U. DET. MERCY L. REV. 267, 286 (2004).

64. Another means of distributing information about the availability of medications is for pharmaceutical companies to convey this information directly to patients through Direct-toConsumer Advertising (DTCA) campaigns. However, DTCA has generated criticism. See Thomas L. Hafemeister \& Richard M. Gulbrandsen, Jr., The Fiduciary Obligation of Physicians to "Just Say No" if an "Informed" Patient Demands Services That Are Not Medically Indicated, 39(2) SETON 
In short, some effects of marketing may be beneficial. However, the negative impacts of pharmaceutical marketing are significant and have been the source of considerable concern. The AMA has stated that pharmaceutical marketing can hurt the physician-patient relationship because "[w]hen physicians accept personal inducements, others [including patients] may perceive that the physicians will not fulfill their professional obligations appropriately and fairly."65 "The American Medical Student Association echoes this sentiment: "By taking gifts, [physicians] are willingly choosing to practice industry-centered, rather than patient-centered, medicine."

Simply put, pharmaceutical marketing impacts physicians' prescribing practices. ${ }^{67}$ Multiple studies have found that pharmaceutical marketing, including the distribution of "freebies"- even if the financial value of the gifts is negligible - taints physicians' medical judgment. ${ }^{68}$ For example, a study by the Cleveland Clinic Foundation "examined the impact $[\mathrm{of}]$... all-expenses-paid trips to popular Sunbelt vacation sites

HALL L. REV. (forthcoming April 2009). Some pharmaceutical companies have used marketing resources to test Direct-to-Consumer Advertising (DTCA) campaigns on physicians. W. John Thomas, Direct-to-Consumer Pharmaceutical Advertising: Catalyst for a Change in the Therapeutic Model in Psychotherapy?, 32 ConN. L. ReV. 209, 217 (1999) (citing Abigail Zuger, Fever Pitch: Getting Doctors to Prescribe Is Big Business, N.Y. TIMES, Jan. 11, 1999, at A1). Although these meetings give physicians a chance to offer feedback and thereby alleviate some physicians' concerns regarding a given DTCA campaign, these "information management" sessions also give sales representatives another opportunity to "push their wares." Id. at 245.

65. Beverley D. Rowley et al., Professionalism and Gifts to Physicians from Industry, in AM. Med. Ass'N, What You SHould KnOw ABout GifTS to PHysicians FROM Industry (2003), at 36, available at $\mathrm{http}: / / \mathrm{www}$.ama-assn.org/ama1/pub/upload/mm/437/ama_m3_pg.pdf.

66. American Medical Student Association, Physician-Industry Relationships ..., http:// www.amsa.org/prof/PharmFreeCheatSheet.pdf (last visited Nov. 1, 2008).

67. Calabro, supra note 4, at 2257 ("Pharmaceutical companies are exerting increasing pressure on physicians' prescription patterns through various means, including providing gifts and other benefits for brand loyalty.").

68. See, e.g., id. at 2259 ("[Marketing undermines] the ability of the physician to make independent determinations concerning the patient's well-being and to function as a learned intermediary."); Jason Dana \& George Loewenstein, A Social Science Perspective on Gifts to Physicians from Industry, 290 JAMA 252, 252 (2003); Fisher, supra note 13, at 213 (Freebies "taint the prescribing process and prevent doctors from making objective assessments of the optimal prescribing choices for their patients."); Kapp, supra note 4, at 249-50 ("[T] here is substantial social science evidence that the subtle, frequently unconscious influence of drug company gifts on physician prescribing behavior may be quite real and powerful... . [I]t appears that the size of the gift does not determine the response; in other words, even gifts of negligible financial value can influence the behavior of the recipient in ways that the recipient does not realize."); Jerome P. Kassirer, Financial Indigestion, 284 JAMA 2156, 2156 (2000); Dana Katz et al., All Gifts Large and Small, 3 Aм. J. Bioethics 39, 39 (2001); Lori-Ann Rickard \& Amy Fehn, Recent Developments in Regulation of Pharmaceutical Marketing Practices, J. HeAlTH L., Dec. 2006, at 16 ("[P]hysician's prescribing practices are, in fact, affected by interactions with drug companies."); Ashley Wazana, Physicians and the Pharmaceutical Industry: Is a Gift Ever Just a Gift?, 283 JAMA 373, 373 (2000). But see Katherine S. Mangan, Strong Medicine for Doctors, CHRON. HigHER EdUC., Jan. 9, 2004 , at A28. 
to attend symposia sponsored by a pharmaceutical company" on the prescribing patterns of physicians. ${ }^{69}$ The study tracked the pharmacies' "usage reports for two drugs before and after the symposia.", the physicians asserting that the symposia would not alter their prescribing patterns, a sizable increase in the prescribing pattern of both drugs occurred following the symposia, which was "significantly different from the national usage patterns of the two drugs by hospitals [and other] major medical centers over the same period of time."

Pharmaceutical marketing has also affected the total number of prescriptions written. Instead of opting for "less risky or expensive approaches" to a medical condition, "such as changes in diet and exercise," often physicians, influenced by marketing, opt for medications. ${ }^{72}$ Even though, in the last decade, the U.S. population has grown by only nine percent, written prescriptions have increased by seventy percent. ${ }^{73}$ Though this could partially be due to an increase in the number of Americans receiving regular health care and to changes in treatment approaches, these explanations are unlikely to account for most of this increase.

According to the national president of the American Medical Student Association, Dr. Michael Ehlert, "marketing practices ... [have] led to over-medicating of the U.S. population."74 Additionally, pharmaceutical companies exert pressure on doctors to switch patients' prescriptions. ${ }^{75}$ "[D]octors are regularly bombarded with letters, calls and faxes - many including offers of cash payments - urging them to stop prescribing

69. James P. Orlowski \& Leon Wateska, The Effects of Pharmaceutical Firm Enticements on Physician Prescribing Patterns: There's No Such Thing as a Free Lunch, 102 CHEST J. 270, 270 (1992).

70. Id.

71. Id.

72. Rebecca Dresser, Pharmaceutical Company Gifts: From Voluntary Standards to Legal Demands, HaStingS CTR. ReP., May-June 2006, at 8.

73. Press Release, American Medical Student Association, Thousands of Medical Students Call on Schools to Eliminate Pharmaceutical Marketing Influence (Oct. 22, 2007), http://www.amsa.org/ news/release2.cfx?id=322.

74. Id.; see also David Blumenthal, Doctors and Drug Companies, 351 New Eng. J. Med. 1885,1885 (2004) (" $[\mathrm{T}]$ he marketing by the drug industry of its products to physicians is manifestly aimed also at improving industry profits; in the process, such marketing may contribute to less savory social consequences, including increasing drug costs and the misuse or overuse of medications in ways that may adversely affect patients.").

75. Peter Keating, Why You May be Getting the Wrong Medicine: A Money Investigation Reveals How Big Drug Companies Are Pressuring Doctors, Pharmacists and Insurers to Push Prescriptions that Benefit Company Bottom Lines-But May Also Harm Your Health, MonEY, June 1,1997 , at 142 . 
certain medications in favor of others." 76 In short, this marketing has affected physicians' prescribing practices. ${ }^{77}$

These findings make intuitive sense as well. Pharmaceutical companies are driven largely by the need to generate profits from their activities. The only justification for spending over $\$ 12$ billion a year on physician marketing must be that it positively impacts sales revenues. Otherwise, pharmaceutical companies would likely curtail this expenditure, thereby adding that $\$ 12$ billion to their bottom line.

Perhaps unexpectedly, sampling, in particular, is troubling as a number of studies have shown that it does not accomplish its stated goals, which are purportedly to allow physicians to try new drugs and to provide needed medications to indigent patients who otherwise could not afford them. For example, in a randomized trial, researchers from the University of Minnesota found that medical residents who used samples were less likely to prescribe cheaper, over the counter medications, and more likely to prescribe advertised drugs than residents who agreed not to use samples. ${ }^{78}$ Another study found that $91 \%$ of physicians dispensed a sample that differed from their preferred drug choice when treating hypertension. ${ }^{79}$ Finally, a third study found that when sample use was barred from a physician's practice, use of an alternative generally recommended first-line antihypertensive drug increased from $38 \%$ to $61 \%{ }^{80}$

Another justification given for sampling, as noted, is to enable physicians to pass medications along to indigent patients. ${ }^{81}$ This is commendable in theory; however, in practice this frequently does not occur. Studies found that $96 \%$ of physicians and staff have taken samples for personal or family use in the preceding year, ${ }^{82}$ that almost

76. Id.

77. See id.

78. Richard F. Adair \& Leah R. Holmgren, Do Drug Samples Influence Resident Prescribing Behavior? A Randomized Trial, 118 AM. J. MED. 881, 882-83 (2005).

79. Lisa D. Chew et al., A Physician Survey of the Effect of Drug Sample Availability on Physicians' Behavior, 15 J. GEN. INTERNAL MED. 478, 478 (2000).

80. John M. Boltri et al., Effect of Antihypertensive Samples on Physician Prescribing Patterns, 34 FAmily Med. 729, 729 (2002); see also David P. Miller et al., The Impact of Drug Samples on Prescribing to the Uninsured, 101 S. MED. J. 888, 891 (2008) ("[P]hysicians are over three times more likely to prescribe generic medications to uninsured patients when drug samples are not available ....").

81. Interview with Barbara Allison-Bryan, M.D. (Nov. 12, 2007).

82. See John M. Westfall et al., Personal Use of Drug Samples by Physicians and Office Staff, 278 JAMA 141, 142 (1997); see also Rita Rubin, Doctors Ditch Drug Samples to Avoid Influencing Treatment, USA TODAY, Dec. 1, 2008, http://www.usatoday.com/news/health/2008-11-30-drugsamples_n.htm ("“[Drug samples are] an unacknowledged gift for physicians and their staff and their families to use."” (quoting Adriane Fugh-Berman, Georgetown University Medical Center physician 
$60 \%$ of pharmaceutical representatives provided samples "to individuals other than physicians," and that almost $50 \%$ of pharmaceutical representatives had "self medicated or provided samples to friends or relatives." 83 This is not only an inappropriate use of these samples, it can be criminal. ${ }^{84}$

It is likely that pharmaceutical marketing capitalizes on the availability heuristic, which posits that people base their prediction of the frequency or likelihood of an event on how easily an example can be brought to mind. ${ }^{85}$ Physicians may be conditioned to diagnose certain diseases or illnesses because marketing has made a physician more likely to be thinking of a specific disorder and jump to conclusions about a possible diagnosis and the course of treatment to be employed. Although instances of outright medical error because of pharmaceutical marketing are difficult, if not impossible, to identify, it is not hard to envision them occurring. ${ }^{86}$

Even if pharmaceutical marketing has not significantly decreased the quality of medical care in this country, marketing to physicians does

and director of PharmedOut, a "publicly funded project to inform doctors about drugmakers' influence")).

83. Kevin L. Tong \& Chia-Yen Lien, Do Pharmaceutical Representatives Misuse Their Drug Samples?, 41 CAN. FAMILY PHYSICIAN 1363, 1363 (1995); see also Sarah L. Cutrona et al., Characteristics of Recipients of Free Prescription Drug Samples: A Nationally Representative Analysis, 98 AM. J. PuB. HEALTH 284, 287 (2008) [hereinafter Cutrona et al., Characteristics] ("We found that $12 \%$ of US residents received free samples during 2003 but less than one third of all sample recipients were low income and less than one fifth of all sample recipients were uninsured at any point during the year."); Sarah L. Cutrona et al., Free Drug Samples in the United States: Characteristics of Pediatric Recipients and Safety Concerns, 122 PEDIATRICS 736, 742 (2008) [hereinafter Cutrona et al., Free Drug Samples] ("Our study demonstrates that poor and uninsured children are not the main recipients of free drug samples. Free samples go primarily to children with the best access to health care; their distribution does not equalize medication access.").

84. See, e.g., 35 PA. StAT. ANN. § 780-113 (West 2003 \& Supp. 2008).

85. See generally John S. Carroll, The Effect of Imagining an Event on Expectations for the Event: An Interpretation in Terms of the Availability Heuristic, 14 J. EXPERIMENTAL SOC. PSYCHOL. 88 (1978).

86. See Monja L. Proctor et al., Incidence of Medical Error and Adverse Outcomes on a Pediatric General Surgery Service, 38 J. PEDIATRIC SURGERY 1361, 1363 (2003) ("Although it is widely recognized that medical error is a significant public health concern, it is difficult to estimate the actual incidence of medical error. Not all mistakes in medical management cause measurable harm to patients, yet most have that potential. Conversely, not all harm caused to patients by medical treatment results from preventable error. For example, prophylactic antibiotics, when indicated, should be administered before making the incision. Failure to administer the antibiotic at the appropriate time is an error, regardless of whether the patient develops a postoperative wound infection, whereas a wound infection may still occur in the absence of any identified error in treatment. The incidence of medical error reported in previous studies has varied from $3 \%$ to $50 \%$, depending on study design and criteria."); see also Cutrona et al., Free Drug Samples, supra note 83, at 736 ("[N]umerous adult studies suggest that free samples influence the prescribing behavior of physicians and trainees. Physicians alter their prescribing patterns when using samples, choosing medications that are more expensive, less likely to be first-line agents, and less likely to be consistent with the physicians' own, self-described, prescribing preferences." (citations omitted)). 
have a significant impact on the cost of care. For example, marketing promotes the use of brand-name medications over generic drugs, even though the latter are considerably cheaper. ${ }^{87}$ Despite the fact that over $70 \%$ of prescriptions are written for drugs for which both generic and brand-name versions are available, fewer than $30 \%$ of prescriptions are written for the generic version. ${ }^{88}$ Because manufacturers of generic drugs spend significantly less on marketing than their brand-name counterparts, doctors are probably "less likely to think of generic alternatives" when writing prescriptions. ${ }^{89}$

In a relatively recent analysis of Medicaid prescription drug spending, two researchers from Brigham and Women's Hospital noted that potential savings of $\$ 229$ million could have been realized from greater use of generic drugs within the Medicaid programs alone. ${ }^{90}$ Most of these unrealized savings were concentrated in a small group of medicines, including Clozaril (clozapine), Xanax (alprazolam), and Levoxyl (levothyroxine), ${ }^{91}$ each of which has been heavily marketed by their respective pharmaceutical companies. ${ }^{92}$ A physician's tendency to prescribe more costly, name-brand medications because of pharmaceutical marketing is worrisome, especially as health care costs, particularly those for drugs, are soaring. ${ }^{93}$

87. Jennifer S. Haas et al., Potential Savings from Substituting Generic Drugs for Brand-Name Drugs: Medical Expenditure Panel Survey, 1997-2000, 142 AnNals InTERnal Med. 891, 891 (2005) (finding that sixty-one percent of multisource drugs were dispensed as generic). "If a generic had been substituted for all corresponding brand-name outpatient drugs in 2000 , the median annual savings in drug expenditures per person would have been $\$ 45.89 \ldots$ for adults younger than 65 years of age and $\$ 78.05 \ldots$ for adults at least 65 years of age." Id. "While the per capita savings of generic substitution appear modest, national savings would be substantial: about $\$ 6$ billion for adults younger than age 65 years and about $\$ 3$ billion for older adults." Id. at 892 . Generic drugs are generally $30-60 \%$ cheaper than their brand-name equivalents. Judith K. Hellerstein, The Importance of the Physician in the Generic Versus Trade-Name Prescription Decision, 29 RAND J. ECON. 108, 108 (1998) (citing Henry G. Grabowski \& John M. Vernon, Brand Loyalty, Entry, and Price Competition in Pharmaceuticals After the 1984 Drug Act, 35 J. L. \& ECON. 331 (1992)).

88. Hellerstein, supra note 87, at 108.

89. Benjamin P. Falit, Curbing Industry Sponsors' Incentive to Design Post-Approval Trials that are Suboptimal for Informing Prescribers but More Likely than Optimal Designs to Yield Favorable Results, 37 Seton HALl L. ReV. 969, 1001 (2007).

90. Michael A. Fischer \& Jerry Avorn, Economic Consequences of Underuse of Generic Drugs: Evidence from Medicaid and Implications for Prescription Drug Benefit Plans, 38 HEALTH SERVS. RES. 1051, 1055 (2003).

91. Id. at 1056,1058 tbl. 3 .

92. Illustrative of this are websites targeted specifically at physicians. See, e.g., Clozaril, http://www.clozaril.com/hcp/index.jsp (last visited Nov. 11, 2008), Xanax XR, http://www.xanax .com/infopro/index.asp (last visited Nov. 11, 2008), Levoxyl, http://www.levoxyl.com/hcp/1.0 phys_info.asp (last visited Nov. 11, 2008). These drugs have also been heavily detailed. Interview with Barbara Allison-Bryan, M.D. (Dec. 3, 2007).

93. As a percentage of Gross Domestic Product (GDP), the United States spent approximately $15 \%$ on health expenditures in 2004 as compared with $8.5 \%$ in 1980 . Other Organisation for 
And finally, with all of the mainstream press coverage of pharmaceutical marketing to physicians, ${ }^{94}$ there is an appearance of impropriety. It can be expected that patients will begin to question the allegiance of their doctors and to doubt the quality and independence of their medical judgment. Many believe that " $t]$ hese interactions are eroding the public's trust in the medical profession." "95 As the American College of Physicians has noted, "[a] perception that a physician is dispensing medical advice on the basis of a commercial influence is likely to undermine a patient's trust not only in the physician's competence but also in the physician's pledge to put patients' welfare ahead of self-interest." $" 96$

Physicians share these concerns about the negative impacts of pharmaceutical marketing. A study published in the Yale Journal of Health Policy Law and Ethics found that physicians have negative or, at best, neutral attitudes about pharmaceutical sales representatives. ${ }^{97}$ The authors reported that when drug promotion is emphasized, physicians leave the interaction with a more negative attitude than if the presentation had been more focused on information and educational support. ${ }^{98}$ Advocacy groups composed of physicians are also vocal in claiming that "pharmaceutical companies continually mislead physicians

Economic Co-operation and Development (OECD) countries, including Germany, France, Canada, Australia, and the United Kingdom have increased their respective spending by only 1 or $2 \%$. In 2004 , Americans spent nearly $\$ 7,000$ per capita on total annual health care, outspending all other OECD countries by approximately $\$ 4,000$. In an effort to keep down costs, insurance companies have begun having pharmacists provide generic versions of any drug prescribed unless the physician specifically insists that the patient receive the brand-name version. Cathy Schoen et al., U.S. Health System Performance: A National Scorecard, 25 Health AfFairs, 2006 Web Exclusives, W457 (2006); see also Maggie Fox, U.S. Healthcare Expensive, Inefficient: Report, ReUTERS, May 15, 2007 ("Americans get the poorest health care and yet pay the most compared to five other rich countries ....").

The increased influence of managed care organizations and other third-party payors of health care costs has resulted in physicians and consumers being increasingly pressured to use less expensive generic drugs, but this, in turn, has led pharmaceutical manufacturers to focus more of their marketing attention on these third-party payors, potentially mitigating any savings. See generally Kevin J. Dunne \& Ciara R. Ryan, How Management of Medical Costs Is Revolutionizing the Drug Industry, 62 DEF. COUNS. J. 177 (1995).

94. See supra note 1 and accompanying text.

95. Testimony on State Laws Requiring Disclosure of Pharmaceutical Company Payments to Physicians: Testimony before the S. Special Comm. on Aging, 110th Cong. 24 (2007) [hereinafter Congressional Testimony] (testimony of Peter Lurie, Joseph S. Ross, Adina H. Rosenbaum, and Jason Krigel), available at http://frwebgate.access.gpo.gov/cgi-bin/getdoc.cgi?dbname $=110$ senate hearings\&docid=f:39865.pdf.

96. Coyle, supra note 38, at 397.

97. Puneet Manchanda \& Elisabeth Honka, The Effects and Role of Direct-to-Physician Marketing in the Pharmaceutical Industry: An Integrative Review, 5 YALE J. HEALTH POL'Y L. \& ETHICS 785, 787 (2005).

98. Id. at 789-90. 
by feeding them erroneous information through their sales representatives or [by] failing to disclose vital information regarding the drug's safety." In October 2007, the American Medical Student Association sponsored "PharmFree Week," calling upon medical schools to eliminate pharmaceutical marketing from their campuses and to "promote liberation from pharmaceutical company influence." 100 The week's activities included congressional lobbying and a symposium to "provide skills [to physicians] to become more critical and evidencebased prescribers." 101 Physicians have also used various medical journals to bring attention to the pharmaceutical industry's negative impact on CME programs, and patient care more generally. ${ }^{102}$ But recognition has grown that mere physician and public awareness of the deleterious impact of pharmaceutical marketing is not enough and a number of measures have been introduced in an effort to curb this impact.

\section{EXISTING EFFORTS to CURB PHARMACEUTICAL MARKETING}

As will be discussed below, professional organizations such as the AMA, the federal and state governments, and even the pharmaceutical industry through the Pharmaceutical Research and Manufacturers of America (PhRMA), ${ }^{103}$ have embraced efforts to deter some of the unacceptably close ties between the pharmaceutical industry and physicians. ${ }^{104}$ The failure of some physicians to voluntarily curtail these unacceptable behaviors has triggered the progressive imposition of legal norms and more fully developed ethical guidelines. ${ }^{105}$

99. Neil F. Hazaray, Note, Do the Benefits Outweigh the Risks? The Legal, Business, and Ethical Ramifications of Pulling a Blockbuster Drug Off the Market, 4 InD. HeAlth L. Rev. 115, 144 (2007).

100. American Medical Student Association, supra note 73.

101. Id.

102. See, e.g., Relman, supra note 43; Samuel Packer \& David Parke, Ethical Concerns in Industry Support of Continuing Medical Education: The Con Side, 122 ARCHIVES OPHTHALMOLOGY 773 (2004).

103. PhRMA is a coalition of pharmaceutical research and biotechnology companies. PhRMA advocates for public policies "that encourage discovery of important new medicines for patients by pharmaceutical/biotechnology research companies." PhRMA, About PHRMA, http://www.phrma. org/about phrma/ (last visited Nov. 2, 2008).

104. Studdert et al., supra note 51, at 1891.

105. Id. at 1892 . 


\section{A. Federal Anti-Kickback Statute}

Using anti-kickback provisions and false claims laws, federal prosecutors have begun pursuing cases involving improper interactions between physicians and pharmaceutical companies. Passed in 1972, the federal anti-kickback statute ${ }^{106}$ was intended to protect the Medicare and Medicaid programs from inappropriate requests for reimbursement by imposing sanctions on suppliers who have sought to induce unnecessary orders for health care products or services by providing remuneration to physicians in exchange for their prescribing these products or services. ${ }^{107}$ "Giving, accepting, or offering to give or accept such remuneration can result in [significant] criminal and civil penalties." 108 Until the early 1990 s, federal prosecutors invoked this law only when "there was clearly an intent to increase referrals-for example, situations in which one physician kicked back a portion of the Medicare payment for a [medical device] to the referring physician or a drug retailer paid a nursing home a monthly fee for the right to act as the facility's preferred supplier." 109

In April 2003, the Office of the Inspector General (OIG) of the U.S. Department of Health and Human Services issued a document for pharmaceutical companies that explained "which industry practices are likely to provoke [federal] prosecution," as well as a series of factors that will influence prosecutorial decisions. ${ }^{110}$ Notably, physicians appear to be just as liable to prosecution as pharmaceutical companies if the OIG determines that their relationship with a pharmaceutical company is suspect. ${ }^{111}$ Unless the relationship between a pharmaceutical company and a physician fits within one of several statutory "safe harbors" as outlined in the anti-kickback statute, ${ }^{112}$ the government will weigh four factors in deciding whether a payment to a physician constitutes a kickback:

[1.] Does the arrangement or practice have a potential to interfere with, or skew, clinical decision-making? Does it have a potential to

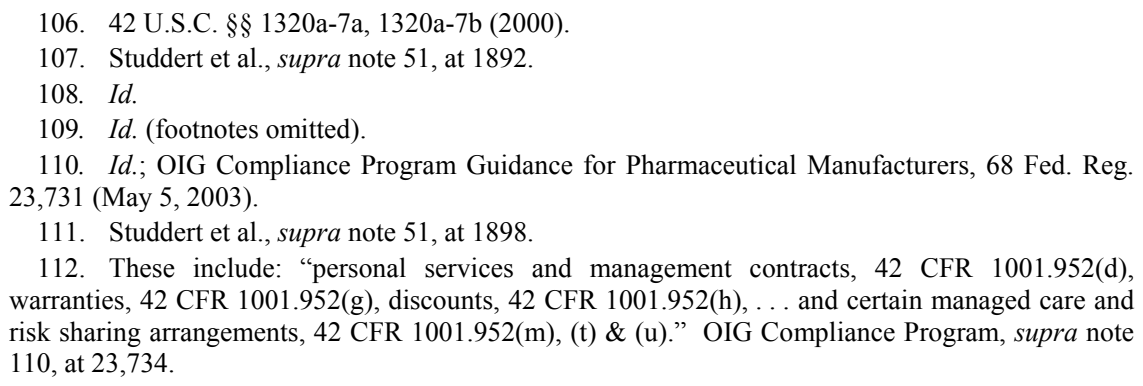


undermine the clinical integrity of a formulary process? If the arrangement or practice involves providing information to decisionmakers, prescribers, or patients, is the information complete, accurate, and not misleading?

[2.] Does the arrangement or practice have a potential to increase costs to the federal health care programs, beneficiaries, or enrollees? Does the arrangement or practice have the potential to be a disguised discount to circumvent the Medicaid Rebate Program Best Price calculation?

[3.] Does the arrangement or practice have a potential to increase the risk of overutilization or inappropriate utilization? [and]

[4.] Does the arrangement or practice raise patient safety or quality of care concerns? ${ }^{113}$

The document also directs that the grant-making functions and the sales and marketing functions within pharmaceutical companies be separated to ensure that the latter does not influence the substance of an educational program. ${ }^{114}$ The guidance also cautions these companies to ensure that organizers of conferences for continuing medical education are not improperly channeling money to physicians. ${ }^{115}$

With respect to funding research, the OIG specifies that "manufacturers [should] develop contracting procedures that clearly separate the awarding of research contracts from marketing" "116 and "[r]esearch contracts that originate through the sales or marketing functions... are particularly suspect." ${ }^{\text {117 }}$ Consulting or advisory services that result in "fair market value payments to small numbers of physicians ... are unlikely to raise[] concern[s]," but paying physicians as consultants to attend meetings and engaging physicians to work in manufacturers' marketing and sales activities are practices that are more suspect. ${ }^{118}$ Entertainment, recreation, travel, meals, gifts, and gratuities for physicians are all potentially subject to anti-kickback prohibitions. ${ }^{119}$

\footnotetext{
113. Id.

114. Id. at 23,735 .

115. Id. at 23,738 . The code of conduct of the Accreditation Council for Continuing Medical Education is referred to as a "useful starting point" for pharmaceutical companies in determining what constitutes an improper channeling of funds to physicians. Id.

116. Id. at $23,735-36$.

117. Id. at 23,736 .

118. Id. at 23,738 .

119. Id. at 23,737 .
} 
In this attempt to regulate industry practices through federal law, the government has been successful in deterring and imposing sanctions on the most egregious abuses. But because the anti-kickback statute is applicable only when a federally or state funded health-care program is involved, ${ }^{120}$ it is a relatively ineffective means for curbing abuses associated with the marketing of medications to physicians in general.

\section{B. Codes and Guidelines Generated by Professional Organizations}

Pharmaceutical companies are aware of the criticism their marketing has engendered and the emerging federal and state responses. They also recognize that excessive marketing practices may undermine the protection from liability afforded them by the learned intermediary doctrine. ${ }^{121}$ As a result, their primary national organization, PhRMA, adopted a Code on Interactions with Healthcare Professionals in July 2002. It emphasizes that interactions between pharmaceutical companies and health care providers should be focused on providing scientific and educational information, that meetings should occur at venues conducive to providing this scientific or educational information, and that "entertainment" such as "dine and dash" (meals paid for by pharmaceutical companies that have little or no educational component) and recreational events like sporting events or spa visits should not occur. ${ }^{122}$ The PhRMA Code also states that although it is acceptable for pharmaceutical companies to continue to provide support for continuing education programs directly to the sponsors of these programs, pharmaceutical companies should not fund the attendance of individual participants. ${ }^{123}$

However, adherence to these recommendations is only voluntary ${ }^{124}$ and the PhRMA Code does not address clinical investigations or consulting payments like those paid to Dr. Carlat for his lunch time presentations. As one commentator pointed out, the guidelines have no legal enforceability and "[i]f following the guidelines would put a

\footnotetext{
120. Calabro, supra note 4, at 2261.

121. See id. at 2264.

122. See PhRMA Code, supra note 50, at 5.

123. See id. at 6 . Starting January 1,2009 , PhRMA also called for a voluntary moratorium on "reminder items" such as branded pens, staplers, flash drives, paperweights, calculators, and notepads. Ceci Connolly, With More Oversight on the Horizon, Drugmakers Work to Polish Image, WASH. POST, Jan. 8, 2009, at A01; Singer, supra note 4, at A1.

124. Provision fifteen of the PhRMA Code regarding adherence only states that "[a]1l companies that interact with health care professionals about pharmaceuticals should adopt procedures to assure adherence to this Code." PhRMA Code, supra note 50, at 14.
} 
company at a competitive disadvantage ... [it] has little choice but to ignore [them]."125

Subsequent to PhRMA's adoption of its Code, the AMA overhauled its own respective ethical code relating to interactions between physicians and pharmaceutical companies. ${ }^{126}$ The AMA's guidelines, adopted in 2004, speak in broad, exhortatory language that calls for caregivers "to place the health and welfare of the patient ahead of [their own] economic self-interest." According to the guidelines, "gifts accepted by physicians... should not be of substantial value" and meetings should be "held at an appropriate location, [and] promot[e] objective scientific and educational activities and discourse." ${ }^{127}$ Meetings should also provide a disclosure of entities providing financial support or potential conflicts of interest. ${ }^{128}$ Like the PhRMA Code, the AMA's guidelines also contain provisions regarding travel expenses, quid pro quo gifts, and scholarships. ${ }^{129}$ The guidelines state that subsidies from pharmaceutical companies should not be accepted "for the costs of travel, lodging, or other personal expenses of physicians attending conferences or meetings." ${ }^{30}$ Quid pro quo gifts are not permitted, but scholarships that would "permit medical students, residents, and fellows to attend... educational conferences may be permissible as long as the selection of students, residents, or fellows ... is made by the academic or training institution."131

As Studdert notes, "[t]he resulting statements [of PhRMA and the AMA] share a focus ... [;] [t]hough the statements differ in scope and specificity, the harmony is striking among the recommendations." 132 These largely parallel codes suggest that there is a consensus within the field that physicians should avoid these marketing efforts; those that do not avoid them violate a professional and, as will be argued, a legal duty to their patients.

\footnotetext{
125. Millrood, supra note 4.

126. Studdert et al., supra note 51, at 1898.

127. AM. MED. Ass'N CODE, supra note 50.

128. Id.

129. Id.

130. Id.

131. Id.

132. Studdert et al., supra note 51, at 1898.
} 


\section{State and Federal Legislative Efforts}

State legislatures have also tried to control the adverse effects of pharmaceutical marketing by enacting laws that limit what pharmaceutical companies can give to physicians and, in some jurisdictions, even mandate that permitted gifts be reported. To date, at least six states have passed legislation that attempts to curtail the negative effects of pharmaceutical marketing to physicians: California, Maine, Massachusetts, Minnesota, Vermont, and West Virginia, as well as the District of Columbia.

California's legislation stands out as it converts the existing voluntary industry codes into legally binding standards. ${ }^{133}$ The legislation "requires pharmaceutical companies to adopt and publicly disclose a comprehensive compliance program" that meets the PhRMA Code, as well as the standards outlined by the Final OIG Guidance, "establish specific annual dollar limits on gifts [and] incentives provided to health care professionals," and make public "an annual declaration of compliance." "134 However, this statute is not without flaw. First, "pharmaceutical company" is defined broadly; it is ambiguous if "out-ofstate pharmaceutical companies doing business in California" are included. ${ }^{135}$ Second, "requiring pharmaceutical companies to comply with the Final OIG Guidance is difficult because [the OIG] merely provided recommendations and not 'requirements."136 According to commentators, "pharmaceutical manufacturers [may have] a tough time ... discerning the subtle differences." 137

Massachusetts has recently addressed the problem of pharmaceutical marketing through legislation. On August 10, 2008, Governor Deval Patrick signed into law Senate Bill 2863, which requires the Massachusetts Department of Public Health (DPH) to establish a pharmaceutical and medical device marketing code of conduct. ${ }^{138}$ It imposes compliance and reporting requirements on pharmaceutical and medical device companies that employ a person to sell or market prescription drugs or medical devices in the state. The conduct of these

133. CAL. Health \& SAFETy Code, $\S \S 119400,119402$ (West 2005); Jonathan K. Henderson \& Quintin Cassady, Drug Deals in 2006: Cutting Edge Legal and Regulatory Issues in the Pharmaceutical Industry, 15 ANNAls HeALTH L. 107, 145 (2006).

134. Henderson \& Cassady, supra note 133, at 145.

135. Id. at 146 .

136. Id.

137. Id.

138. Todd Wallack, Tied Up Over Disclosure: Life Sciences Firms Anxious About Rules on Gifts to Doctors, Boston GloBe, Aug. 13, 2008, at C1. 
employees must at least meet the PhRMA Code and similar guidelines issued by the Advanced Medical Technology Association. And, the statute establishes certain specific prohibitions, some of which are more restrictive than the PhRMA Code. ${ }^{139}$

However, the Massachusetts statute does not impose a deadline for the development of the DPH marketing code (although the law does require that once the DPH code is established it must be updated every two years). ${ }^{140}$ This may allow the DPH (which may be strapped for time and resources) to significantly delay the writing and implementation of this code.

The other four states, and the District of Columbia, have passed various statutes that require pharmaceutical companies to disclose payments, or other items of value, made to physicians. ${ }^{141}$ Each law has its own combination of requirements, but generally mandates some combination of disclosure to a state government agency, the public, or the state legislature. ${ }^{142}$ Included in the report (depending on the specific law) may be a requisite itemized report of each payment. ${ }^{143}$

These statutes mark progress. They strive "to increase the transparency" of interactions between physicians and pharmaceutical companies. ${ }^{144}$ However, they "all fall well short" of what needs to be accomplished. ${ }^{145}$ Inexplicably, none of the statutes calls for the reporting of payments relating to the marketing of biologics (a biological product like a vaccine or blood serum) $;{ }^{146}$ and only Massachusetts's addresses medical devices. ${ }^{147}$ Two of the six states (Minnesota and West Virginia) do not mandate individualized reporting of payments, permitting reports

139. MaSs. Gen. LAWS ANN. ch. 111N, § 2 (effective Jan. 1, 2009). For example, the Massachusetts law prohibits the "provision of or payment for meals directly at any CME event, third-party scientific or educational conferences, or professional meetings." Id. § 2(6). The PhRMA Code contains no similar provision.

140. Id. $\S 2$

141. See D.C. Code $\S 48-833$ (Supp. 2008); Me. Rev. Stat. AnN. tit. 22, § 2698-A (2004); MinN. Stat. ANN. § 151.47 (West 2005); VT. Stat. ANN. tit. 33, § 2005 (2007); W. VA. CodE ANN. § 5A-3C-13 (West Supp. 2008).

142. See, e.g., D.C. CODE $\S 48-833.01$ (requiring pharmaceutical manufacturers distributing drugs in the District of Columbia to report marketing costs to the District of Columbia Department of Health); MinN. STAT. ANN. § 151.47.1(f) (requiring that wholesale drug distributors file with a state board the nature and value of payments over $\$ 100$ to practitioners in Minnesota and stating that this information is public).

143. See, e.g., D.C. CODE $§ 48-833.03$ ("“T]he annual report filed ... shall include the following information as it pertains to marketing activities conducted within the District in a form that provides the value, nature, purpose, and recipient of the expense.").

144. Congressional Testimony, supra note 95.

145. Id.

146. Id.

147. MASS. GEN. LAwS ANN., ch. 111N, § 2(8) (effective Jan. 1, 2009). 
to be aggregated "either across payment type or by physician." 148 West Virginia's statute is one of the weakest: "each company is required only to report (in dollar ranges) the total value of payments in that year and the number of physicians who received payments"; the names of physicians who received payments are not required. ${ }^{149}$ Furthermore, West Virginia has no enforcement mechanism available under its law to sanction a failure to report. ${ }^{150}$

"Although these statutes typically require that food, travel, and honoraria [or] consulting fees be reported, exclusions from mandated reporting are common." 151 As the authors of a 2007 report (i.e., prior to the Massachusetts enactment) analyzing the statutory provisions of the District of Columbia, Maine, Minnesota, Vermont, and West Virginia found: "[t]he threshold for any reporting ranges from $\$ 25$ (District of Columbia, Maine, and Vermont) to $\$ 100$ (Minnesota and West Virginia). Four states (all except Minnesota) exempt certain payments related to medical conferences and research studies from the reporting requirement, and all exempt free samples for patients." 152

"Only the [Massachusetts and] Minnesota statutes make[] all the disclosed information part of the public record, without exception, although the remaining four states require annual summary reports to the legislature. A model statute would require both." ${ }^{153}$

A comparable statute was proposed to the United States Congress on July 12 , 2007, by Representative Peter DeFazio (D-OR). ${ }^{154}$ Entitled the

148. Congressional Testimony, supra note 95; MinN. STAT. ANN. § 151.47.1(f) (West 2005) (permitting aggregation by physician); W. VA. CODE ANN. § 5A-3C-13(a) (West Supp. 2008) ("Advertising costs for prescription drugs, based on aggregate national data, must be reported to the state council .....").

149. Congressional Testimony, supra note 95; W. VA. CODE ANN. § 5A-3C-13 (West Supp. 2008).

150. Congressional Testimony, supra note 95.

151. Id.

152. Id.

153. Id.

154. H.R. 3023, 110th Cong. (2007). The Senate counterpart was S. 2029, 110th Cong. (2007). On January 22, 2009, Senators Charles Grassley (R-IA) and Herb Kohl (D-WI) introduced the Physician Payments Sunshine Act of 2009, which would require manufacturers of pharmaceuticals, medical devices, and biologics that receive payments through Medicare, Medicaid, or the State Children's Health Insurance Program (SCHIP) to report to the Department of Health and Human Services (DHHS) anything over $\$ 100$ in value that they give to physicians, with the DHHS in turn directed to make this information available online. Maribel Rios, Physician Payments Sunshine Act Reintroduced for 2009, PHARMTECH.COM, Jan. 29, 2009, http://pharmtech.findpharma.com/ pharmtech/News/Physician-Payments-Sunshine-Act-Reintroduced-for-2/ArticleStandard/Article/ detail/577973? contextCategoryId=35097; S. 301, 111th Cong. (2009). 
Drug and Medical Device Company Gift Disclosure Act, ${ }^{155}$ this bill had many of the same weaknesses as its state counterparts. The bill required:

Each manufacturer ... of a drug ... or of a device shall disclose to the [Food and Drug Administration] Commissioner ... the value, nature, and purpose of any-(i) gift provided, directly or indirectly, ... to any covered health entity by the manufacturer, packer, or distributor, or a representative or agent thereof, in connection with detailing, promotional, or other marketing activities; and [any]... (ii) cash rebate, discount, or any other financial consideration provided during the preceding calendar year to any pharmaceutical benefit manager by the manufacturer ... or a representative or agent thereof, in connection with detailing, promotional, or other marketing activities.

However, the bill excluded samples, compensation and reimbursements for conducting clinical trials, and scholarships to attend an "educational, scientific, or policy-making conference." ${ }^{157}$ With the exception of trade secrets, the bill required the Food and Drug Administration (FDA) Commissioner to "make all information disclosed ... publicly available, including . . . posting such information on the Internet," was no mandated annual report to Congress regarding these disclosures.

Not requiring disclosures of clinical trials and scholarships presents similar problems as the various state statutes do that exempt them. Additionally, the provision exempting trade secrets from on-line disclosure could have made the bill's reporting feature meaningless. The pharmaceutical industry would likely attempt to get their marketing practices categorized as a trade secret. If these efforts were routinely successful, the effectiveness of the proposed reporting mechanism would be significantly curtailed. Regardless, at the close of the 110th Congress, both the House and Senate versions of the bill died in Committee without becoming law.

Though commendable for focusing on the problems associated with the marketing of pharmaceuticals to physicians, the federal anti-kickback statute, currently existing state legislation, and the bills introduced in the House and Senate, each lack sufficient scope and enforceability to be effective.

155. H.R. $3023 \S 1$.

156. Id. § 2; see also Wayne J. Guglielmo, Will Your Free Dinner Appear Online?, MED. ECON., Oct. 19, 2007, at 13; Dave Hansen, Bill Would Make Drug Firms Disclose Gifts to Doctors, AM. Med. News, Oct. 1, 2007; Dave Hansen, House to Offer Bill for Registry of Drug Firm Gifts to Doctors, AM. MED. News, Nov. 26, 2007.

157. H.R. 3023.

158. Id. 


\section{Health Systems' Ban on Physicians Accepting Trinkets}

Some health systems, including those associated with the University of California at Davis, Stanford University, Yale University, University of Pennsylvania, a group of hospitals and clinics in northern Minnesota, and Detroit's Henry Ford Health Systems have banned the drug industry's practice of giving physicians items of relatively limited value (hereinafter referred to as "trinkets") altogether. ${ }^{159}$ Physicians from a health system in Duluth turned in over 18,000 items they had been given, "including clocks, mugs, surgical caps, calculators, tape dispensers, and a stress-relieving squeeze toy made to look like a red blood cell.,"160 According to one report, the "backlash against the cozy relationships between doctors and drug [manufacturers] "161 became more prominent after a 2006 Journal of the American Medical Association (JAMA) article stated that "research had shown that even cheap gifts, such as pens, can affect [physicians]' prescribing decisions."

The 2006 JAMA article, entitled Health Industry Practices That Create Conflicts of Interest: A Policy Proposal for Academic Medical Centers, ${ }^{163}$ and others ${ }^{164}$ report that "the impulse to reciprocate for even small gifts is a powerful influence on people's behavior. Individuals receiving gifts are often unable to remain objective; they reweigh information and choices in light of the gift."165

159. Jacob Goldstein, Health System Bans Drug Rep Trinkets, Wall Street J. Health BloG, Jan. 18, 2008, http://blogs.wsj.com/health/2008/01/18/health-system-bans-drug-rep-trinkets/; Steve Karnowski, Minnesota Health System Purges Drug Trinkets, L.A. TIMES, Jan. 19, 2008; U.C. Davis Health System, UC Davis Health System Bans Receipt of Gifts from All Vendors, July 7, 2007, http://www.ucdmc.ucdavis.edu/welcome/features/20070711_nogifts/; Henry Ford Bans Pharma Perks, Vendor Drop-ins, Dec. 14, 2006, http:/www.fiercehealthcare.com/story/henry-ford-banspharma-perks-vendor-drop-ins/2006-12-15; see also Morgan Lewis Jr., Wisconsin Med Society Bans Pharma Gifts, MED. ECON., Dec. 5, 2008, http://www.modernmedicine.com/modernmedicine/ article/articleDetail.jsp?id=569316 ("The Wisconsin Medical Society has prohibited its members from accepting gifts - including personal items, office supplies, food, travel and time costs, or payment for participation in online continuing medical education-from any provider of products that they prescribe to their patients.").

160. Goldstein, supra note 159.

161. Karnowski, supra note 159 .

162. Id. (referring to Troyen Brennan et al., Health Industry Practices That Create Conflicts of Interest: A Policy Proposal for Academic Medical Centers, 295 JAMA 429 (2006)).

163. Brennan et al., supra note 162 .

164. See, e.g., Iserson et al., Politely Refuse the Pen and Note Pad: Gifts from Industry to Physicians Harm Patients, 84 ANNALs THORACIC SURGERY 1077, 1078 (2007) ("Receiving industry gifts compromises professionalism and your fiduciary duty to your patients.").

165. Brennan et al., supra note 162 , at 431. 


\section{E. Impact of Legislative and Professional Organization Efforts to Curb Pharmaceutical Marketing}

Each of the attempts described above to limit pharmaceutical marketing is commendable; however, they have failed to resolve the problem. Anti-kickback statutes, though potentially effective when prosecutors target services covered by federal or state funded healthcare programs, cannot reach abuses outside this context. State statutes, in addition to being enacted in only a handful of states, are relatively limited in scope and fail to address several key marketing channels that can compromise the medical judgment of physicians. Finally, voluntary codes adopted by organizations like PhRMA and the AMA are just that-voluntary.

Although some of the more egregious practices, such as free trips to golf and ski resorts, may no longer be as prevalent, efforts to date have failed to eradicate arguably more subtle forms of pharmaceutical marketing that compromise physicians' medical judgment. Furthermore, the publicity given to pharmaceutical marketing, as well as the potential conflict of interests and clouding of physicians' decision-making that may result from this practice, poses the potential to undercut the level of trust that patients need to place in their physicians for health care to be appropriately delivered. At the same time, a consensus has emerged regarding the dangers of pharmaceutical marketing among physicians and the need to curb the abuses that have been associated with it. This consensus has led physicians acting in good faith (and the professional organizations that represent them) to voluntarily curb these abuses. The development of this consensus provides the cornerstone for encouraging and expecting all physicians to follow this path. Although pharmaceutical companies can and should be deterred from engaging in abusive marketing practices, the competitive nature of their enterprise and the need to maximize their profit will likely limit the impact of efforts to curtail these practices. In addition, the special nature of the patient-physician relationship and the responsibility of physicians to protect and promote the interests of their patients places on physicians an obligation to avoid situations where pharmaceutical marketing has the potential to compromise their medical judgment. 


\section{A FIDUCIARY DUTY}

Ethical duties do not always give rise to legal obligations. ${ }^{166}$ Although the AMA (as well as PhRMA) has promulgated guidelines, such guidelines do not (except perhaps in California with regard to the PhRMA guidelines) ${ }^{167}$ carry with them explicit legal obligations. However, those guidelines can establish what a physician is expected to do. This, in turn, can establish the foundation for what behavior is required of a physician under the common law doctrine of trusts. ${ }^{168}$ More active application of this legal obligation will alleviate many of the problems associated with pharmaceutical marketing.

\section{A. What Is a Fiduciary Relationship?}

A hallmark of fiduciary law is its flexibility to accommodate new situations as they arise. ${ }^{169}$ Originally, fiduciary doctrine was the courts' response "to the absence of a remedy ... for beneficiaries injured by the disloyalty of [their] trustees." 170 Over time, this doctrine has been extended beyond the trustee-beneficiary relationship to other relationships in which a party (the fiduciary) is entrusted with the responsibility to act and make decisions on behalf of another individual (the beneficiary), with the expectation that the fiduciary will seek to promote the beneficiary's welfare. ${ }^{171}$ Fiduciary relationships have been

166. See generally AMERICAN PSYCHOLOGY ASSOCIATION, ETHICAL PRINCIPALS OF Psychologists AND CODE OF CONDUCT (2002) ("The Preamble and General Principles are aspirational goals to guide psychologists toward the highest ideals of psychology. Although the Preamble and General Principles are not themselves enforceable rules, they should be considered by psychologists in arriving at an ethical course of action.").

167. See supra notes 133-37 and accompanying text.

168. This Article explores the fiduciary duty of physicians arising from the doctrine of trusts. It is also possible to envision the fiduciary duty of physicians, discussed in this Article, to stem from the principles of quasi-contract, fraud, or tort, including the doctrine of informed consent. It should be noted, as discussed infra note 182, that the breach of a fiduciary duty is viewed today by the courts as largely sounding in tort. Nevertheless, the roots of this cause of action are deeply imbedded in the common law doctrine of trusts and the following discussion in this subsection proceeds from this foundation. For a further discussion of these roots and their impact on this cause of action, see Hafemeister \& Gulbrandsen, supra note 64, and Thomas L. Hafemeister \& Selina Spinos, A Physician's Fiduciary Duty to Disclose Emergent Medical Risk, 86 WASH. U. L. REV. (forthcoming June 2009). However, space constraints prevent an exploration here of these potential alternative foundations for physicians' fiduciary duty to their patients.

169. See Roy Ryden Anderson \& Walter W. Steele, Jr., Fiduciary Duty, Tort and Contract: A Primer on the Legal Malpractice Puzzle, 47 SMU L. REV. 235, 239 (1994).

170. See Maxwell J. Mehlman, Dishonest Medical Mistakes, 59 VAND. L. REV. 1137, 1147-48 (2006).

171. Id. at 1147. 
found to exist between partners of a company, ${ }^{172}$ directors and companies, ${ }^{173}$ attorneys and clients, ${ }^{174}$ agents and principals, ${ }^{175}$ stockbrokers and clients, ${ }^{176}$ and, directly relevant to this discussion, physicians and patients. ${ }^{177}$

Fiduciary rules are designed to ensure that the fiduciary fulfills his or her obligations and does not neglect, abuse, exploit, or otherwise take advantage of the relatively vulnerable and dependent beneficiary. ${ }^{178}$ This enables the beneficiary to receive needed assistance from the fiduciary, albeit with a general expectation that the fiduciary will be compensated for his or her services. Because a more formal relationship would involve relatively high transaction and monitoring costs, ${ }^{179}$ the relationship itself tends to be informal; however, the nature of the obligations imposed on the fiduciary are derived from a recognition that the dependent and vulnerable beneficiary must be able to trust and rely upon the fiduciary.

Generally, the fiduciary owes a duty of utmost loyalty to the beneficiary, which entitles the beneficiary to place complete trust in the

172. See, e.g., Leff v. Gunter, 658 P.2d 740, 744 (Cal. 1983); Wash. Med. Ctr., Inc. v. Holle, 573 A.2d 1269, 1285 (D.C. 1990); Couri v. Couri, 447 N.E.2d 334, 337 (Ill. 1983); Barksdale v. Lincoln Builders, Inc., 764 So. 2d 223, 230 (La. Ct. App. 2000); Starr v. Fordham, 648 N.E.2d 1261, 1265 (Mass. 1995); Covalt v. High, 675 P.2d 999, 1001 (N.M. Ct. App. 1983).

173. See, e.g., FDIC v. Jackson, 133 F.3d 694, 699 (9th Cir. 1998) (applying Arizona law); Henash v. Ipalook, 985 P.2d 442, 445 (Alaska 1999); Small v. Fritz Cos., 65 P.3d 1255, 1262 (Cal. 2003); Ostrowski v. Avery, 703 A.2d 117, 121 (Conn. 1997); Mynatt v. Collis, 57 P.3d 513, 526 (Kan. 2002); Hill v. Se. Floor Covering Co., 596 So. 2d 874, 877 (Miss. 1992).

174. See, e.g., In re Gonzalez, 773 A.2d 1026, 1031 (D.C. 2001); In re Ryan, 670 A.2d 375, 379 (D.C. 1996); Sage Realty Corp. v. Proskauer Rose Goetz \& Mendelsohn L.L.P., 689 N.E.2d 879, 882 (N.Y. 1997); Ruden v. Jenk, 543 N.W.2d 605, 610 (Iowa 1996); STAR Ctrs. v. Faegre \& Benson, L.L.P., 644 N.W.2d 72, 77 (Minn. 2002); In re Bernstein, 774 A.2d 309, 312 (D.C. 2001).

175. See, e.g., Sim v. Edenborn, 242 U.S. 131, 135-36 (1916); Costos v. Coconut Island Corp., 137 F.3d 46, 48 (1st Cir. 1998) (applying Maine law); Evvtex Co. v. Hartley Cooper Assocs., 102 F.3d 1327, 1332 (2d Cir. 1996) (applying New York law); Arguello v. Conoco, Inc., 207 F.3d 803, 807 (5th Cir. 2000).

176. See, e.g., First Union Disc. Brokerage Servs., Inc. v. Milos, 744 F. Supp. 1145, 1156 (S.D. Fla. 1990); Walston \& Co. v. Miller, 410 P.2d 658, 660-61 (Ariz. 1966) (holding that an agency relationship normally terminates with execution of the order); E.F. Hutton \& Co. v. Weeks, 304 S.E.2d 420, 422 (Ga. App. 1983).

177. See, e.g., Canterbury v. Spence, 464 F.2d 772, 782 (D.C. Cir. 1972); United States v. Neufeld, 908 F. Supp. 491, 500 (S.D. Ohio 1995); Salis v. United States, 522 F. Supp. 989, 997 n.10 (M.D. Pa. 1981); Hammonds v. Aetna Cas. \& Sur. Co., 237 F. Supp. 96, 102 (N.D. Ohio 1965); Mull v. String, 448 So. 2d 952, 953 (Ala. 1984); Hales v. Pittman, 576 P.2d 493, 497 (Ariz. 1978); Cobbs v. Grant, 502 P.2d 1, 12 (Cal. 1972); Stafford v. Shultz, 270 P.2d 1, 7 (Cal. 1954); Berkey v. Anderson, 82 Cal. Rptr. 67, 78 (Cal. Ct. App. 1969); Simmons v. Univ. of Chi. Hosps. and Clinics, 642 N.E.2d 107, 111 (Ill. 1994); Petrillo v. Syntex Labs., Inc., 499 N.E.2d 952, 960-61 (Ill. App. Ct. 1986); Henkin, Inc. v. Berea Bank \& Trust Co., 566 S.W.2d 420, 423 (Ky. Ct. App. 1978); Woolley v. Henderson, 418 A.2d 1123, 1128 n.3 (Me. 1980).

178. Mehlman, supra note 170 , at $1147-48$.

179. Id. 
fiduciary. ${ }^{180}$ This obligation flows from (1) "the discretionary control that [the fiduciary] usually has over a significant aspect of the [beneficiary's] life or assets," and (2) the discrepancy between the interests of the fiduciary and the beneficiary, which may in some circumstances directly conflict. ${ }^{181}$

\section{B. Establishing a Claim for Breach of a Fiduciary Duty ${ }^{182}$}

As in negligence actions where a plaintiff must establish duty, breach, causation, and harm to prevail, plaintiffs pursuing a fiduciary cause of action need to prove the existence of a fiduciary relationship, that the defendant breached his or her fiduciary obligations, and, in some states, that there is damage proximately caused by the breach. ${ }^{183}$ However, at that point, the burden shifts to the fiduciary to prove that he or she, in fact, acted as any other fiduciary could have reasonably been

180. BLACK's LAW Dictionary 545 (8th ed. 2004) (defining "fiduciary duty"). Components of this duty are that the fiduciary speak with candor and respect the confidences of the beneficiary. Id.

181. Anderson \& Steele, supra note 169, at 240 (citing Kenneth B. Davis, Jr., Judicial Review of Fiduciary Decisionmaking - Some Theoretical Perspectives, 80 Nw. U. L. REV. 1, 4 (1985)).

182. Both in theory, and in practice, the breach of a fiduciary duty constitutes a tort. The Second Restatement of Torts reads, "[a] fiduciary who commits a breach of his duty as a fiduciary is guilty of tortious conduct to the person for whom he should act." RESTATEMENT (SECOND) OF TORTS § 874, cmt. b (1979) ("Violation of Fiduciary Duty"). A number of courts have so held, or stated this in dicta. See, e.g., Resolution Trust Corp. v. Gaudet, 192 F.3d 485, 487 (5th Cir. 1999); FDIC v. Abraham, 137 F.3d 264, 266-67 (5th Cir. 1998); Walter v. Drayson, No. CV 06-00568 SOM-KSC, 2007 WL 2694399, at *4 (D. Haw. Sept. 12, 2007); Filson v. Radio Adver. Mktg. Plan, LLC, 553 F. Supp. 2d 1074, 1086 (D. Minn. 2008); Harmelin v. Man Fin. Inc., No. 06-1944, 2007 WL 2739579, at *3 (E.D. Pa. Sept. 20, 2007); Barber v. Fox, 632 N.E.2d 1246, 1249 (Mass. App. Ct. 1994); Tennen v. Hyman, No. 268173, 2007 WL 1828603, at *5 (Mich. Ct. App. June 26, 2007); Doe v. Roman Catholic Diocese of Rochester, 857 N.Y.S.2d 866, 867 (N.Y. App. Div. 2008); Zuba v. Pawtucket Credit Union, 941 A.2d 167, 173 (R.I. 2008) (dictum); Turner v. PV Int'l Corp., 765 S.W.2d 455, 461 (Tex. App. 1988). Some courts have determined that claims of breach of a fiduciary duty may sound in contract. See, e.g., Collins v. Reynard, 607 N.E.2d 1185 (Ill. 1992); see also Anderson \& Steele, supra note 169 , at 260 n.165. But this may be the result of an understandable confusion. Fiduciary relationships usually begin with either an express or implied contractual agreement that establishes, for example, employment, brokerage authority, or the provision of legal, financial, or medical services. But "[c]ontract law generally assumes that parties bargain at arms length, whether or not the parties actually share equal bargaining leverage, and that the resulting bargain governs their relationship." Anderson \& Steele, supra note 169, at 241. Fiduciary relationships, in contrast, are not conducted at arm's length. Id. at 242. As a result, for fiduciary relationships, "the law jettisons the general presumptions and standards of the law of contract and applies instead the stricter fiduciary standard." Id. at 242 (citing Deborah A. DeMott, Beyond Metaphor: An Analysis of Fiduciary Obligation, 1988 Duke L. J. 879, 896 (1988)). Although express terms of an underlying agreement may still be relevant when determining the fiduciary's obligation, the agreement does not control as it would under contract law. Id.

183. See, e.g., Cramer v. Devon Group, Inc., 774 F. Supp. 176, 184 (S.D.N.Y. 1991); City of Atascadero v. Merrill Lynch, 80 Cal. Rptr. 2d 329, 355 (Cal. Ct. App. 1998) (requiring damage); Jonas v. Jonas, 633 S.E.2d 544, 549 (Ga. Ct. App. 2006) (requiring damage). 
expected to act under similar circumstances. ${ }^{184}$ Further, unlike negligence actions, fiduciaries cannot cite the beneficiary's contributory or comparative negligence as a defense to a breach of fiduciary duty claim. ${ }^{185}$

\section{Duty}

The plaintiff must first prove that a fiduciary relationship between the plaintiff and the defendant existed at the time of the alleged breach. ${ }^{186}$ This establishes that the defendant, as a fiduciary, had a duty to fulfill his or her fiduciary obligations to the beneficiary. The specific duties of the fiduciary will vary depending on the nature of the relationship and the particular circumstances involved; for example, a trustee, the director of a corporation, a guardian, an attorney, and a physician will each have somewhat different responsibilities to fulfill to satisfy their obligations as a fiduciary. ${ }^{187}$

However, the general obligations are relatively similar as fiduciary law expects fiduciaries to meet a basic standard of conduct. ${ }^{188}$ The fiduciary must exercise undivided loyalty to the interests of the beneficiary and "is required in all matters to further the best interests of and to exhibit and to practice fairness and honesty toward the [beneficiary]." 189 It has been described by one court as a duty of "uberrima fides" or a "'most abundant good faith,' requiring absolute and perfect candor, openness and honesty, and the absence of any concealment or deception." 190

Fiduciaries must act to protect and enhance the best interests of the beneficiary and cannot use their position to promote their own interests at the expense of the beneficiary. They are held to the highest level of loyalty and good faith, are prohibited from putting themselves in positions where their interests and the beneficiary's interests conflict, and

184. Cf. Anderson \& Steele, supra note 169, at 253 (1994) ("Although the client retains the ordinary burdens of pleading and proof regarding causation and damages, the attorney has the full burden of proving that [he] has not violated [his] fiduciary obligation - that [he] has dealt fairly with [his] client and that [his] actions were not only acceptable but were above reproach." (citations omitted)).

185. Id. at 254 (citing Koral Indus. v. Security-Connecticut Life Ins. Co., 802 S.W.2d 650, 651 (Tex. 1990); Isenhower v. Bell, 365 S.W.2d 354, 357 (Tex. 1963)).

186. E.g., Cramer, 774 F. Supp. at 184.

187. Meredith J. Duncan, Legal Malpractice by Any Other Name: Why a Breach of Fiduciary Duty Claim Does Not Smell as Sweet, 34 WAKE FOREST L. REV. 1137, 1151-52 (1999).

188. Id. at 1152 .

189. Id.

190. Perez v. Kirk \& Carrigan, 822 S.W.2d 261, 265 (Tex. Ct. App. 1991) (citations omitted). 
must, in any direct dealing with the beneficiary (or the legal representative of the beneficiary if the beneficiary lacks decision-making capacity), make full disclosure of all facts relevant to the fiduciary relationship and give the latter an opportunity to obtain independent advice. ${ }^{191}$

\section{Breach}

Violating these fiduciary obligations constitutes a breach of fiduciary duty. "Once the patient provides evidence of a breach of fiduciary duty, the burden typically shifts to the physician to disprove the allegation."192 Because the beneficiary is not in a position to fully establish either the actions of the fiduciary, the circumstances that existed at the time, or whether any conflict of interests compromised the judgment or actions of the fiduciary, the burden shifts to the fiduciary to show that he or she, in fact, acted as a fiduciary could reasonably be expected to act under the circumstances. ${ }^{193}$ The breach of one's fiduciary duties can be found to exist irrespective of a lack of moral culpability on the part of the

191. See, e.g., Starr v. Fordham, 648 N.E.2d 1261, 1265 (Mass. 1995) ("Partners owe each other a fiduciary duty of the highest degree of good faith and fair dealing."); Hill v. Se. Floor Covering Co., 596 So. 2d 874, 877 (Miss. 1992) (holding that the general manager of flooring company owed a "duty to exercise the utmost good faith and loyalty"); In re Gonzalez, 773 A.2d 1026, 1031 (D.C. 2001) (holding that an attorney owes a fiduciary duty to his client and must serve the client's interests with the utmost loyalty and devotion); Salm v. Feldstein, 799 N.Y.S.2d 104, 105 (N.Y. App. Div. 2005) (stating that "[a]s the managing member of the company and as a comember with the plaintiff, the defendant owed the plaintiff a fiduciary duty to make full disclosure of all material facts"); Goffney v. Rabson, 56 S.W.3d 186, 193 (Tex. App. 2001) ("Breach of fiduciary duty by an attorney most often involves the attorney's failure to disclose conflicts of interest, failure to deliver funds belonging to the client, placing personal interests over the client's interests, improper use of client confidences, taking advantage of the client's trust, engaging in self-dealing, and making misrepresentation."); In re DeSousa, 826 N.Y.S.2d 306, 308 (N.Y. App. Div. 2006) (holding that "[the attorney] engaged in conduct adversely reflecting on his fitness to practice as a lawyer by breaching his fiduciary duty by failing to advise [his client] to seek advice of independent counsel and aiding her in the preparation of documents which bestowed a financial interest upon the [attorney]").

192. Mehlman, supra note 170, at 1148 (citing Demers v. Gerety, 515 P.2d 645, 655 (N.M. Ct. App. 1973), rev'd, 520 P.2d 869 (N.M. 1974) ("In a fiduciary relationship, the burden is on the defendant to show scrupulous good faith in obtaining an express written authority to operate or to extend the operation when it conflicts with the unequivocal beliefs of the patient.")); see also Smith v. Tele-Commc'n, Inc., 184 Cal. Rptr. 571, 575 (Cal. Ct. App. 1982); Konover Dev. Corp. v. Zeller, 635 A.2d 798, 810 (Conn. 1994); Labovitz v. Dolan, 545 N.E.2d 304, 311 (Ill. App. Ct. 1989); Sampson v. Hunt, 665 P.2d 743, 754 (Kan. 1983); Gaynier v. Ginsberg, 715 S.W.2d 749, 754 (Tex. App. 1986); Wilkins v. Lasater, 733 P.2d 221, 228 (Wash. Ct. App. 1987)).

193. Cf. Anderson \& Steele, supra note 169, at 253 ("[T]he attorney has the full burden of proving that [he] has not violated [his] fiduciary obligation - that [he] has dealt fairly with [his] client and that [his] actions were not only acceptable but were above reproach." (citations omitted)). 
fiduciary because of the dependence and vulnerability of the beneficiary and the level of trust imbued in the fiduciary. ${ }^{194}$

\section{Causation and Harm}

As alluded to previously, many states do not have either a causation requirement or an actual harm requirement associated with their fiduciary causes of action. ${ }^{195}$ This is in part because (1) the breach of loyalty is the harm and (2) the purpose behind recognizing breach of fiduciary duty claims is to remove the incentive for disloyal conduct on the part of the fiduciary by confiscating the profits gained by fiduciaries as a result of their conduct, not necessarily to restore beneficiaries to their position ex ante by compensating their losses. ${ }^{196}$ If, however, actual harm and causation can (or must) be shown, the plaintiff may become eligible for additional remedies as discussed below.

\section{Remedies}

Because in many fiduciary causes of action there is no, or minimal, actual harm, damages often focus on any unjust enrichment gained by the fiduciary from the breach. ${ }^{197}$ The monetary value of this enrichment should be returned to the beneficiary. ${ }^{198}$ This award is designed to directly address the fiduciary's breach of the obligation of loyalty that the fiduciary owes to the beneficiary.

But if the beneficiary experiences actual harm, damages may be awarded to compensate the beneficiary for actual loss or injury suffered

194. Duncan, supra note 187 , at 1154.

195. 1 Geoffrey C. Hazard, Jr. \& W. William Hodes, The LaW of Lawyering: A HANDBooK ON THE Model Rules of Professional CONDuct $\S$ 1.5:108 (2d ed. Supp. 1987) (explaining that, in a breach of fiduciary duty claim, the breach of loyalty is the harm and the client is not required to prove causation or specific injury); Duncan, supra note 187, at 1154-55; see also George T. Bogert, Trusts \& TRustees § 543 (2d. ed. Rev. 1993) ("Trustee's Duties In General"); Milbank v. Boon, 13 F.3d 537, 543 (2d Cir. 1994); Zackiva Commc'ns Corp. v. Horowitz, 826 F. Supp. 86, 88 (S.D.N.Y. 1993); Diamond v. Oreamuno, 248 N.E.2d 910, 912 (N.Y. 1969); Rice v. Perl, 320 N.W.2d 407, 411 (Minn. 1982).

196. HAZARD \& Hodes, supra note 195, § 1.5:108; Stewart E. Sterk, Trust Protectors, Agency Costs, and Fiduciary Duty, 27 CARdozo L. REV. 2761, 2802 (2006).

197. See, e.g., Williams v. Stanford, 977 So. 2d 722, 730 (Fla. Dist. Ct. App. 2008); Sack v. Feinman, 413 A.2d 1059, 1065-66 (Pa. 1980) (holding that breaches of fiduciary duty are remediable by returning to the complainant the benefit taken by the offending party); Robertson v. ADJ P'ship, Ltd., 204 S.W.3d 484, 494 (Tex. App. 2006) (noting that "disgorgement of profits has long been recognized as an appropriate remedy for . . . breach of fiduciary duty").

198. See, e.g., Williams, 977 So. 2d at 730; Sack, 413 A.2d at 1065-66. 
as a result of the fiduciary's breach of duty. ${ }^{199}$ When awarded, these damages are intended to put the beneficiary in the same position that he or she would have been in had the breach not taken place. ${ }^{200}$ Special damages can be assigned to compensate the claimant for quantifiable monetary losses suffered by the beneficiary, while general damages may be awarded to compensate the beneficiary for the non-monetary aspects of the specific harm suffered. ${ }^{201}$ General damages are usually awarded only when beneficiaries have suffered personal harm (e.g., personal injury or defamation). ${ }^{202}$ Finally, punitive damages may also be available if there was malice on the part of the fiduciary. ${ }^{203}$

\section{Breach of Fiduciary Duty Claims in the Context of Trust Law and Its Application to the Patient-Physician Relationship}

Fiduciary relationships are commonly established with the creation and management of a trust. A closer exploration of this particular fiduciary relationship will both illuminate the traditional claim of breach of fiduciary duty and provide guidance for delineating the fiduciary duty of a physician with regard to pharmaceutical marketing.

Traditionally, a trust is an arrangement in which money or property is managed by an entity (the trustee, who is one person, a group of people, or an organization) at the request of someone else (the settlor) for the benefit of another (the beneficiary). ${ }^{204}$ The property is owned by the trustee but held and managed on behalf of the beneficiary. Trusts are most frequently used when "outright gifts [to the beneficiary] would not effectuate the donor's true intent" (e.g., gifts to individuals who lack the

199. See, e.g., APC Filtration, Inc. v. Becker, No. 07-CV-1462, 2008 WL 3008032, at *7 (N.D. Ill. Aug. 4, 2008) ("Under Illinois law, an employer is entitled to lost profits and compensatory damages resulting from an employee's breach of fiduciary duty."); Shapiro, Lifschitz \& Schram, P.C. v. Hazard, 24 F. Supp. 2d 66, 75 (D.D.C. 1998) ("Defendants ... must allege facts from which proximate cause and injury may be inferred if they seek compensatory damages ....").

200. BLACK's LAW DiCTIONARY, supra note 180, at 416-19 (defining "damages").

201. Id. at 417,419

202. Newton v. Hornblower, Inc., 582 P.2d 1136, 1140 (Kan. 1978); Campbell v. State Farm Mut. Auto. Ins. Co., 65 P.3d 1134 (Utah 2001), rev'd on other grounds, 538 U.S. 408 (2003).

203. Daniel J. Pope \& Suzanne Lee, Breach of Fiduciary Duty and Punitive Damages, 66 Def. Coun. J. 257, 264-65 (1999) (citing Smith v. Lightning Bolt Prods., 861 F.2d 363 (2d Cir. 1988)); Bank Saderat Iran v. Telegen Corp., No. C-94-2330-VRW, 1997 WL 685247 (N.D. Cal. Oct. 16, 1997); In re Legal Econometrics Inc., 191 B.R. 331 (Bankr. N.D. Tex. 1995), aff'd in part \& vacated in part sub nom. Vaughn v. Akin, No. 3-95-CV-0457-R, 1997 WL 560617 (N.D. Tex. Aug. 29, 1997); Home Ins. Co. v. Wynn, 493 S.E.2d 627 (Ga. Ct. App. 1997); Fairfax Sav., F.S.B. v. Weinberg \& Green, 685 A.2d 1189 (Md. Ct. Spec. App. 1996); Fiedler v. Adams, 466 N.W.2d 39 (Minn. Ct. App. 1991); Rizzo v. Haines, 555 A.2d 58 (Pa. 1989)).

204. BLACK's LAW DictionARY, supra note 180, at 1546 (defining "trust"). 
independence, maturity, or financial skills needed to manage the property effectively). ${ }^{205}$

A trustee's fiduciary duty has been described as inherent in the trust relationship. Sometimes called the rule of undivided loyalty—or simply the loyalty rule - it has been stated as follows:

A trustee is under a duty to the beneficiary of the trust to administer the trust solely in the interest of the beneficiary. The trustee must exclude all self-interest, as well as the interest of a third party, in his administration of the trust solely for the benefit of the beneficiary. The trustee must not place himself in a position where his own interests or that of another enters into conflict, or may possibly conflict, with the interest of the trust or its beneficiary. Put another way, the trustee may not enter into a transaction or take or continue in a position in which his personal interest or the interest of a third party is or becomes adverse to the interest of the beneficiary. ${ }^{206}$

Even though the trustee is the legal owner of the property in the trust, enabling the trustee to manage the property as needed, the trustee is obligated to suppress his or her own interests and take those steps that best serve the interests of the beneficiary. In this way, the beneficiary obtains value from the property without being its technical owner.

The fiduciary duty doctrine was applied to trustees to control three aspects of the typical trustee-beneficiary relationship: the disparity of knowledge between the trustee and the beneficiary, the trustee's ability to act relatively unilaterally, and the vulnerability and dependence of the beneficiary on the trustee. ${ }^{207}$ These three traits are also routinely present in the physician-patient relationship. First, the physician, nearly always, has a superior understanding of the medical facts and diagnostic and treatment protocols than the patient, resulting in a huge disparity of knowledge between the two. ${ }^{208}$ Second, the patient does not have the authority, or the ability, to order diagnostic tests or to prescribe pharmaceuticals. Finally, if the patient's health is at risk, it is likely that the patient is worried or afraid, leaving the patient particularly vulnerable and dependent on the physician. ${ }^{209}$

205. Gerry W. Beyer, Purposes and Uses of Trusts, (Aug. 14, 2008), http://www.professor beyer.com/Trusts_Course/Purposes_Uses_of_Trusts.htm.

206. BOGERT, supra note $195, \S 543$.

207. See Don J. Manderscheid, First Nations and Self-Government: A Matter of Trust, 22 CAN. J. L. SoC'Y 109, 110-11 (2007); see also Mehlman, supra note 170, at 1147-48 (discussing the origins of the fiduciary duty and identifying these motivating concerns as well).

208. Additionally, physicians do things that are difficult for a patient to monitor (e.g., the physician's review of laboratory results).

209. Mehlman, supra note 170, at 1139. 
In light of these parallel concerns, it is not surprising that physicians may be ascribed a fiduciary duty with regard to their patients. ${ }^{210}$ The patient-physician relationship has been held to encompass fiduciary duties such as confidentiality; ${ }^{211}$ testifying in judicial proceedings about treatment rendered the patient; ${ }^{212}$ disclosing information to the patient such as a potential cause of action against the fiduciary, ${ }^{213}$ emergent medical risks, ${ }^{214}$ and, more generally, all information relevant to treatment $;{ }^{215}$ and acting in good faith toward the patient. ${ }^{216}$ For example, in Moore v. Regents of the University of California, the California Supreme Court held that a physician has a fiduciary duty to disclose personal interests (either research or economic) unrelated to the patient's health that may affect the physician's medical judgment. ${ }^{217}$

This fiduciary duty of physicians should also encompass an obligation to avoid placing themselves in situations where pharmaceutical marketing has the potential to compromise their medical judgment. Just as a trustee is required to suppress his or her own interests and take those steps that best serve the interests of the beneficiary, the physician must eschew all pharmaceutical marketing that has the potential to compromise patient care. As discussed, physicians may gain by serving as receptors of marketing (e.g., free lunches and reduced conference attendance fees), ${ }^{218}$ but they do so at the risk of

210. See, e.g., United States v. Vasquez-Ruiz, No. 00CR1044, 2002 WL 1880127, at *2 (N.D. Ill. Aug. 12, 2002) (stating that "[a] fiduciary duty is implicit in the relationship between physician and patient"), rev'd on other grounds, 502 F.3d 700 (7th Cir. 2007); Branom v. State, 974 P.2d 335, 342 (Wash. Ct. App. 1999) (describing the physician-patient relationship as a fiduciary one); State ex rel. Kitzmiller v. Henning, 437 S.E.2d 452, 454 (W. Va. 1993) (holding "that a fiduciary relationship exists between a physician and a patient"). But see Gunter v. Huddle, 724 So. 2d 544 (Ala. Civ. App. 1998) (stating that "Alabama caselaw holds that a physician-patient relationship is not a fiduciary relationship as a matter of law").

211. See, e.g., State ex rel. Dean v. Cunningham, 182 S.W.3d 561, 566 (Mo. 2006) (recognizing "a fiduciary duty of confidentiality owed by a treating physician to his or her patients not to disclose information received in connection with treatment").

212. See, e.g., Stigliano v. Connaught Labs., Inc., 658 A.2d 715, 720 (N.J. 1995) (ruling that the "relationship between treating physicians and their patients, sometimes described as fiduciary in nature, gives rise to a duty to testify in judicial proceedings about treatment rendered to the patient").

213. See, e.g., Fowles v. Lingos, 569 N.E.2d 416, 420 (Mass. App. Ct. 1991) ("[T]he doctorpatient relationship is a fiduciary one, and there may be some circumstances where there is a duty to disclose a cause of action." (citation omitted))

214. See Hafemeister \& Spinos, supra note 168.

215. See, e.g., Hammonds v. Aetna Cas. \& Sur. Co., 237 F. Supp. 96, 102 (N.D. Ohio 1965).

216. See, e.g., Tracy v. Merrell Dow Pharm., Inc., 569 N.E.2d 875, 879 (Ohio 1991) (finding that "[t]he physician-patient relationship is fiduciary [in nature,] based on trust and confidence[,] and obligat[es] the physician to exercise good faith" in fulfilling their obligations).

217. Moore v. Regents of the Univ. of Cal., 793 P.2d 479, 483 (Cal. 1990).

218. See supra Parts III-IV. 
diminishing the quality of patient care they offer. ${ }^{219}$ As previously stated, if the patient's interests are undercut, the physician's fiduciary obligation to the patient is breached.

There are, however, aspects of the trustee-beneficiary relationship that do not fully match the physician-patient relationship and that necessitate a somewhat different approach in applying the fiduciary duty doctrine in this context. First, unlike trustees, physicians do not become the "owner" of that for which they are responsible. In other words, physicians never "own" the patient or the patient's body and they can not exercise absolute control over it. Nonetheless, they potentially wield enormous influence over what the patient does and the treatment and care the patient receives. As a result, they have a corresponding duty to ensure that the information and directions that patients receive from them are not tainted or biased by conflicting interests.

\section{Breach of the Fiduciary Duty to Avoid Pharmacentical Marketing}

A physician's fiduciary duty to avoid pharmaceutical marketing should be firmly embraced. As discussed above, pharmaceutical marketing substantially impacts the choices physicians make when prescribing medications, potentially creating a conflict of interests and compromising their medical judgment. Physicians should avoid pharmaceutical marketing to preserve the trustworthiness of their medical decisions and to provide the highest quality of care possible to their patients. Recognizing the existence of this duty, however, does not necessitate a ban on the dissemination of information by pharmaceutical companies about their products.

Generally, the fiduciary duty of physicians to avoid pharmaceutical marketing ought to be straightforward, without opportunities to evade or minimize the duty. One can state this duty as follows:

Physicians have a fiduciary duty to avoid pharmaceutical marketing when their patients' interests may be compromised.

This obligation is consistent with the principles recognized by states that have passed legislation dealing with pharmaceutical marketing and generally embraced by professional organizations. ${ }^{220}$ This duty requires that physicians refrain from accepting visits from pharmaceutical representatives, free lunches, "trinkets," and travel or other subsidies to

219. See supra Parts III-IV.

220. See supra Part IV. 
attend conferences or programs from pharmaceutical companies. By extension, it also requires that physicians extricate the pharmaceutical companies' presence (both substantively and financially) at CME programs. Finally, it mandates that physicians who have an active patient caseload not directly participate in any marketing activities on behalf of a pharmaceutical company that could be viewed by a patient as compromising the physician's medical judgment. Physicians who accept these gifts or who engage in these marketing activities may subject themselves to a claim for breach of fiduciary duty by a patient.

As is the case for a traditional breach of fiduciary duty claim, a plaintiff pursuing such a claim against a physician must initially establish that a fiduciary relationship existed between the patient and the physician at the time of the purported breach. However, the plaintiff need only make a prima facie case that the physician's medical judgment was compromised with regard to the patient's care as a result of pharmaceutical marketing, which generally can be established by showing that the physician was the recipient of gifts from a pharmaceutical company or participated in marketing activities that were relevant to the medical care delivered by the physician to the patient. Once this prima facie case is shown, the physician then bears the burden of proving that his or her medical judgment was not compromised by the pharmaceutical marketing by showing that he or she acted as a reasonable fiduciary (i.e., physician) would have been expected to act under similar circumstances. ${ }^{221}$

Shifting the burden of proof in this manner and employing an objective standard to ascertain the expected behavior of the physician is appropriate. As alluded to above, it would be very difficult for the plaintiff to establish what the physician's state of mind was as a result of the physician's interactions with the pharmaceutical company and whether this marketing compromised the physician's medical judgment. Ordinarily, the patient does not have direct access to this information and the physician is in a much better position to address these issues. Nevertheless, to deter the filing of spurious claims, the plaintiff must make a prima facie case showing that the physician was the recipient of gifts from a pharmaceutical company or participated in marketing

221. As is the case with regard to many legal questions pertaining to physicians, guidancealbeit instructive, not determinative-for how a reasonable physician would act under the circumstances can be drawn from the standards of professional conduct embraced by and governing the behavior of the profession (e.g., the Code of Medical Ethics adopted by the American Medical Association). 
activities that were relevant to the medical care delivered by the physician to the patient.

Unless required within that jurisdiction, the plaintiff does not have to prove that the patient experienced actual harm (although a lack of actual harm, as discussed below, may result in only a de minimis award for damages). Relatedly, the plaintiff will also not be required to establish a causal link between the breach of a physician's fiduciary duty and resulting harm to the patient. ${ }^{222}$ As discussed in general, this variation from traditional tort doctrine is in part because the breach of loyalty is the harm and because the purpose behind recognizing a breach of fiduciary duty claim in this context is to deter disloyal conduct on the part of the physician (i.e., conflicts of interests that may impede physicians' exercise of independent medical judgment), as opposed to restoring patients to their position ex ante by compensating for their losses.

In the absence of harm and causation requirements, however, there must be some mechanism to control which patients may bring a claim. Because a given physician is likely to have many patients, to avoid calamitous judgments when there has been no showing of actual harm, the physician should be allowed to establish that the gifts the physician received or the marketing activities in which the physician participated were not relevant to the medical care delivered by the physician to the patient. For example, a claim for breach of fiduciary duty would be defeated if a physician was treating a patient for a condition unrelated to the marketing involved. ${ }^{223}$

After successfully establishing that a breach of fiduciary duty occurred, damages should be available. The focus will often be on assessing what benefit was gained by the physician from the breach of duty, which in turn could be awarded to the beneficiary. For example, the plaintiff could be entitled to recover the value of the gifts given to the physician (although this could be nominal in the case of "trinkets"

222. As will be discussed, however, if a plaintiff can show that the patient experienced direct harm and that the physician's breach of fiduciary duty was the causal agent of this harm, the resulting availability of compensatory damages can result in a larger award. See infra notes 224-26 and accompanying text.

223. The focus of this fiduciary cause of action is whether a physician has been disloyal to a patient by placing him or herself in a position where his or her independent medical judgment may have been compromised by a conflict of interest. If the marketing activity in which the physician has been involved is unrelated to the medical care or treatment afforded the patient, there is no basis to conclude that the physician's medical judgment with regard to that patient was compromised. If, for example, a patient is being treated for a heart condition and a physician has accepted free samples for the treatment of athlete's foot, that patient has no basis for concluding that the physician's medical judgment with regard to his or her treatment was influenced. 
received by the physician). An alternative route could be for the plaintiff to show that the patient chose to obtain services from this physician because the physician's participation in various marketing activities gave the physician a reputation as being an "expert" in a given field germane to the patient's medical needs. The "benefit" obtained wrongfully by the physician in this case would be the profits or perhaps even the revenue the physician received as a result of providing medical services to the patient. In general, as is typically the case with fiduciaries that have breached their duty to a beneficiary, the physician should be required to provide an accounting of the "profits" gained.

The patient may also be eligible for an equitable remedy of restitution $^{224}$ or compensatory damages for economic or non-economic harms. $^{225}$ However, such awards may be difficult to assign when no actual damage was shown. These remedies are intended to make a patient "whole," offering recovery for any physical, financial, or emotional injury suffered because of the physician's failure to avoid pharmaceutical marketing. ${ }^{226}$ But these damages will be especially hard to quantify here, if they exist at all.

In addition, punitive damages may be appropriate in a breach of fiduciary duty claim. ${ }^{227}$ Many courts and commentators agree that the prevailing patient should be eligible for punitive damages, especially in cases of extreme disloyalty when malice was present. ${ }^{228}$ To prove this malice, typically a plaintiff should have to show that the doctor knew that harm to the patient would follow from his or her behavior, and yet the physician still failed to take steps to avoid pharmaceutical marketing. Given the abundance of reports about the negative effects of pharmaceutical marketing, this knowledge and intent could potentially be inferred to all practicing physicians directly involved in pharmaceutical marketing today. Furthermore, in failing to avoid the potentially

224. Mehlman, supra note 170, at 1148-49; see also Thomas R. McLean \& Edward P. Richards, Managed Care Liability for Breach of Fiduciary Duty After Pegram v. Herdrich: The End of ERISA Preemption for State Law Liability for Medical Care Decision Making, 53 FLA. L. REV. 1, 44-46 (2001) (discussing equitable and compensatory relief for breach of fiduciary duty).

225. Mehlman, supra note 170, at 1156-57.

226. McLean \& Richards, supra note 224, at 44-46.

227. Mehlman, supra note 170, at 1149.

228. Id. at 1149; see, e.g., Rhue v. Dawson, 841 P.2d 215, 227 (Ariz. Ct. App. 1992) (holding that punitive damages are available in breach of fiduciary duty cases); In re Estate of Hoellen, 854 N.E.2d 774, 787 (Ill. App. Ct. 2006) (holding that punitive damages can be awarded for intentional breach of fiduciary duty without an award of actual damages); Schafer v. RMS Realty, 741 N.E.2d 155, 197 (Ohio Ct. App. 2000) (holding that an award of punitive damages may be appropriate on a claim for breach of fiduciary duty upon a showing of malice); see also E. Haavi Morreim, Medicine Meets Resource Limits: Restructuring the Legal Standard of Care, 59 U. PITT. L. REV. 1, 71 n.245 (1997) (citing scholarship, cases, and treatises in support of this contention). 
deleterious effects of pharmaceutical marketing, a physician violates his or her professional ethical code as well as the legal duty of a fiduciary, making punitive damages potentially more appropriate in a breach of fiduciary duty case than in a medical malpractice case, where such damages are rarely awarded. ${ }^{229}$

\section{E. Retaining the Positive Benefits of Pharmaceutical Marketing}

It can be argued that imposing a fiduciary duty on physicians to avoid pharmaceutical marketing may negatively impact patient care in at least two ways. ${ }^{230}$ First, it can be contended that it will curtail

229. Barry R. FurRow et Al., Liability AND Quality Issues IN Health CARE 243 (5th ed. 2004) ("Punitive damages are extremely rare."). For a discussion of how a failure to adhere to the standards of their profession constitutes the foundation for a breach of fiduciary duty claim against physicians, see Hafemeister \& Spinos, supra note 168.

230. Although beyond the scope of this Article, there are also at least two First Amendment challenges that may be raised regarding the recognition of a physician's fiduciary duty to avoid pharmaceutical marketing. For one, pharmaceutical companies may assert that it infringes their right to engage in commercial speech. The First Amendment protects advertising as a form of commercial speech. As summarized by the Supreme Court:

The commercial market place, like other spheres of our social and cultural life, provides a forum where ideas and information flourish. Some of the ideas and information are vital, some of slight worth. But the general rule is that the speaker and the audience, not the government, assess the value of the information presented. Thus, even a communication that does no more than propose a commercial transaction is entitled to the coverage of the First Amendment.

Edenfield v. Fane, 507 U.S. 761,767 (1993). The pharmaceutical companies may argue that directing physicians to avoid pharmaceutical marketing will eviscerate their ability to promote their products and constitute an unconstitutional infringement of their right to engage in commercial speech.

The constitutional protections for commercial speech, however, are weaker than for private speech. While the Supreme Court has often acknowledged constitutional protection for commercial speech, the Court has recognized the "'common sense' distinction between speech proposing a commercial transaction, which occurs in an area traditionally subject to government regulation, and other varieties of speech." Ohralik v. Ohio State Bar Ass'n, 436 U.S. 447, 455-56 (1978) (citing Va. Pharmacy Bd. v. Va. Citizens Consumer Council, Inc., 425 U.S. 748, 771 n.24 (1976)). This distinction has led the Court to conclude that "[t]he Constitution ... affords a lesser protection to commercial speech than to other constitutionally guaranteed expression." United States v. Edge Broad. Co., 509 U.S. 418, 426 (1993) (citations omitted). The established four-part test for assessing governmental restrictions on commercial speech is:

[First, the commercial speech] at least must concern lawful activity and not be misleading. Next, we ask whether the asserted governmental interest is substantial. If both inquiries yield positive answers, we must determine whether the regulation directly advances the governmental interest asserted, and whether it is not more extensive than is necessary to serve that interest.

Cent. Hudson Gas \& Elec. Corp. v. Pub. Serv. Comm'n, 447 U.S. 557, 566 (1980). A pivotal question would be whether recognizing this fiduciary duty promotes a governmental interest and is not more extensive than is necessary to serve that interest. In addition, it is worth noting that the imposition of a fiduciary duty on physicians to avoid pharmaceutical marketing does not restrict pharmaceutical marketers from continuing to speak by promoting their drugs through other 
pharmaceutical support for medical research. Second, it may be asserted that it will eliminate the availability of free samples of medications for patients who are otherwise unable to afford these medications.

For example, without clinical trials, new and needed medications cannot obtain the required approval from the FDA. ${ }^{231}$ Pharmaceutical companies rely heavily on practicing physicians recruiting their patients to participate in these trials. ${ }^{232}$ If the fiduciary duty of physicians precludes them from conducting these trials, it may be more difficult for pharmaceutical companies to conduct the necessary widespread studies, which could impede valuable medications from receiving FDA approval. Plus, these clinical studies - in which patients are typically not required to pay for the medications they are receiving-may make treatment unavailable to patients who could not otherwise afford it.

Similarly, as discussed earlier, physicians often accept samples of medications from pharmaceutical companies ostensibly to pass them along to patients who are unable to afford the retail price of the medicine or who would find it difficult to travel to a pharmacy in a timely fashion to obtain a needed medication. ${ }^{233}$ As also noted, this does not always happen in practice because these medications are often given to patients who can afford and readily obtain them, or they are diverted to other

marketing channels. However, the pharmaceutical industry may respond that this fiduciary duty removes its primary audience, leaving its speech nearly pointless. Although this issue cannot be resolved within the confines of this Article, it is worth noting that one of the recommendations described below, namely the establishment of a neutral third party as a vehicle for disseminating pharmaceutical samples and related information, provides a means for this industry to continue to engage in commercial speech that reaches physicians. In addition, as also discussed below in the text, indirect or inadvertent contacts with the pharmaceutical industry, particularly when there are no gifts or compensation directed to the physician involved, do not constitute a breach of the physician's fiduciary duty and thus does not preclude this industry from engaging in various other forms of commercial speech (e.g., advertising in medical journals) in an attempt to bring information about their products to the attention of physicians.

Finally, it should be recognized that physicians may raise First Amendment claims; namely that their right to hear speech or their right to associate with the pharmaceutical marketers is being infringed by this fiduciary duty. Although to the authors' knowledge no such claim has been raised (successfully or unsuccessfully) in response to medical codes of ethics or various state and federal efforts that seek to limit pharmaceutical marketing - suggesting that there is not a lot of support for such claims - it is still a potential challenge that could be applied to a recognition of a physician's fiduciary duty to avoid pharmaceutical marketing. Beyond recognizing that neutral third parties could be used to disseminate pharmaceutical samples and related information to physicians, thus ensuring that physicians could hear the speech and maintain links with pharmaceutical companies, this too is beyond the scope of this Article.

231. See 21 C.F.R. $\$ 314.50$ (2008).

232. Christian D'Avignon-Aubut, Certifying the Validity and Integrity of Reports on Clinical Studies Submitted to the FDA: A New Role for a New Breed of Lawyers, 20 GeO. J. Legal ETHICS 499, 502 (2007).

233. See Interview with Barbara Allison-Bryan, supra note 81 and accompanying text. 
purposes. $^{234}$ In addition, most of the time, the samples are brought into the medical office or hospital by detailers ${ }^{235}$ and were not requested by a physician. $^{236}$

However, as discussed, both of these practices have the potential to insidiously compromise the independent medical judgment of the physician and jeopardize the physician's duty of undivided loyalty to a patient. ${ }^{237}$ Better alternatives are available.

For example, instead of having samples being made available on a selective basis by detailers, pharmaceutical companies that wish to distribute free samples of their products to raise awareness of them and encourage their use could be required to give these samples, as well as information about these products, to a neutral third party that does not provide direct medical care to patients. ${ }^{238}$ This third party would collect these samples from the various pharmaceutical companies and make the samples and information about these products (although not necessarily the marketing information provided by the pharmaceutical company) available to physicians who request them. On a regular basis, the third party would distribute a list of the drugs it has in stock and information about the drugs it has compiled. Physicians, upon the routine receipt of this list, could then request those medicines that they want for their office. The medicine would be delivered free of charge to the physician and would be available for in-office distribution to patients. In this way, physicians would have a range of products from which to choose, would not be subject to marketing information that may be presented to favor

234. See Westfall et al., supra note 82, at 142 and accompanying text; Tong \& Lien, supra note 83, at 1363-64 and accompanying text; see also Cutrona et al., Characteristics, supra note 83, at 287 ("[L]ess than one third of all [free drug] sample recipients were low income and less than one fifth . . . were uninsured at any point during the year.").

235. Fisher, supra note 13, at 210.

236. Interview with Barbara Allison-Bryan, M.D. (Mar. 23, 2008). This is an effort to capitalize on the availability heuristic. Detailers will, upon the written request of the physician, provide specified product samples from their company as well. Alan M. Fisch, Compulsory Licensing of Pharmaceutical Patents: An Unreasonable Solution to an Unfortunate Problem, 34 JURIMETRICS J. 295, 309 (1994).

237. See supra Part III.

238. This neutral third party could be a governmental agency, a non-governmental organization that may be established or funded by the government, or perhaps an established community clinic that already makes medications directly available to patients in need (although their distribution activities would need to be kept separate from any clinical services they provide). See also Rubin, supra note 82 ("By April 1, [2009,] none of the [University of Pittsburgh Medical Center's] 530 practice sites will accept samples from drug reps. Instead, doctors can turn to the e-Sample Center, a 'virtual sample closet' ... . [University of Pittsburgh] doctors can [then] order samples online from participating makers, who ship them for free."); Lewis, supra note 159 (noting that the Wisconsin Medical Society recently required its members to "instead use a system of vouchers for evidencebased drug choices"). 
the product being marketed, and would be able to work with a neutral third party who can provide existing and emerging information about the products, as well as collect information about concerns that may be raised regarding a given distributed product.

Presumably, this will significantly diminish the effects of the availability heuristic and enhance the physician's exercise of independent medical judgment. Before ordering a medication from the third-party supplier, the physician will have to make a conscious choice as to which samples to order and consider the likely merits of the medication. The physician can then make a thoughtful choice about whether giving a patient this particular product is in that patient's best interest. It also allows physicians to learn about new pharmaceuticals and other products on the market and permits healthy competition between established and emerging products. ${ }^{239}$

Similarly, the recognition of the fiduciary duty of physicians to avoid pharmaceutical marketing may necessitate revamping the way in which clinical research is conducted. Other commentators have expressed concern about pharmaceutical companies' involvement in clinical research in general and have called for change. ${ }^{240}$ As for pharmaceutical samples, it may be appropriate and timely to involve neutral third parties. Medical practitioners, particularly those who are also trying to juggle a full patient case load, may not be the most appropriate individuals to gather the requisite information regarding the effects of the medications being studied. In addition, concerns have been raised about the reliability and neutrality of clinical studies conducted by pharmaceutical companies when their very existence may depend on the outcome of the study. ${ }^{241}$ A neutral third party, possibly the same entity responsible for

239. There are some potential drawbacks to this approach. For example, by inserting a third party into these transactions, the cost of providing samples to patients may increase. Someone must pay for the services provided by these third parties. Pharmaceutical companies may be willing to fund these services, particularly if they conclude that this is the best way of bringing their product to the attention of physicians. In light of the large amounts they are spending on marketing, they may actually determine that this is a more cost-effective means of disseminating information about their products and welcome this alternative. Alternatively, funding might be provided by the government or by private donors if they conclude that this is a needed public service that will enhance the quality of health care in this country.

240. See, e.g., Joel R. Lexchin, Implications of Pharmaceutical Funding on Clinical Research, 39 ANNALS PSYCHOTHERAPY 194, 195 (2005); Chopra, supra note 37, at 114; Is the UniversityIndustrial Complex Out of Control?, 409 NATURE 119, 119 (2001); Jacob Goldstein, Nobel Laureate Calls for Public Funding of Drug Trials, WALL ST. J., Dec. 16, 2008, http://blogs.wsj.com/ health/2008/12/16/nobel-laureate-calls-for-public-funding-of-drug-trials/ (citing Arjun Jayadev \& Joseph Stiglitz, Two Ideas to Increase Innovation and Reduce Pharmaceutical Costs and Prices, 28 HEALTH AFFAIRS 165 (2009)).

241. See, e.g., COUNCIL On SCIENTIFIC AfFAirs, AMERICAN MEdiCAl Association, Featured Report, Influence of Funding Source on Outcome, Validity, and Reliability of Pharmaceutical 
distributing pharmaceutical samples and related information, may be an appropriate alternative that can enhance confidence in these studies and avoid creating conflicts of interest for treating physicians. Physicians seeking to obtain free treatment for their patients can instead refer their patients to these third parties who also control the distribution of pooled funds originating from pharmaceutical companies designated for clinical research.

Finally, it is worth noting that the fiduciary duty of physicians to avoid pharmaceutical marketing does not reach indirect or inadvertent contacts with the pharmaceutical industry, particularly when there are no gifts or compensation directed to the physician involved. There remains a need for physicians to be informed about new medications or emerging applications of older medications that may prove beneficial to their patients. Certainly, merely reading articles in medical journals that receive support from a pharmaceutical company regarding research that was funded by a pharmaceutical company does not violate a physician's duty to avoid pharmaceutical marketing. Similarly, physicians should not face sanctions for breach of fiduciary duty for simply opening and reading mail or flyers sent to them by a pharmaceutical company promoting their programs. Such contacts are not sufficiently insidious to constitute a conflict of interest and to compromise the physician's independent medical judgment. Indeed, the dissemination of this information may be vital in providing physicians with information about both the benefits and risks of the medications they are employing or may employ.

\section{CONCLUSION}

Pharmaceutical marketing currently pervades the practice of medicine. Unfortunately, in some forms it can have potentially severe and adverse consequences for the quality of patient care. Despite the fact that professional organizations such as the AMA and many states have adopted or passed ethical guidelines and statutes, respectively, admonishing or prohibiting physicians from accepting gifts or compensation from agents of pharmaceutical companies seeking to market their products, the practice has not stopped.

Research (A-04) (2004), available at http://www.ama-assn.org/ama/pub/category/14314.html; see also David B. Resnik, Disclosing Conflicts of Interest to Research Subjects: An Ethical and Legal Analysis, 11 ACCOUNTABILITY IN RESEARCH 141, 144 (2004) ("There is considerable evidence of a connection between the source of research funding and the outcomes of biomedical research studies." (citation omitted)). 
This Article has proposed recognizing the physicians' fiduciary duty to their patients as a means to more fully deter physicians from accepting these gifts and thereby ensure that the well-being of their patients remains their focus. It will also reassure patients that they can trust and rely on the undivided loyalty of their physicians.

As part of their fiduciary duty to their patients, physicians have a legal obligation to avoid placing themselves in situations where pharmaceutical marketing has the potential to compromise their medical judgment. While this fiduciary duty does not reach indirect or inadvertent contacts with the pharmaceutical industry, particularly when there are no gifts or compensation directed to the physician involved, physicians who violate their fiduciary obligation, even if it does not directly harm a patient, may face a claim of breach of fiduciary duty brought by or on behalf of their patient. Although compensatory damages may be awarded if warranted, the availability of punitive damages in this context serves as a further incentive for physicians to comply with this duty. Two carefully circumscribed exceptions to this duty, one for clinical research sponsored by pharmaceutical companies and another for the creation of a third-party distribution system for pharmaceutical samples, will preserve many of the positive benefits of marketing. By recognizing this fiduciary duty, physicians will be encouraged to abstain from inappropriate exposure to pharmaceutical marketing and thereby return the practice of medicine to what should be its patient-centered focus. 